Final Report

FHWA/IN/JTRP-2002/1

\title{
COUNTING DEVICE SELECTION AND RELIABILITY: SYNTHESIS STUDY
}

\author{
By \\ Srinivas Peeta \\ Associate Professor of Civil Engineering \\ and \\ Pengcheng Zhang \\ Graduate Research Assistant \\ Purdue University \\ School of Civil Engineering \\ Joint Transportation Research Program \\ Project Number: C-36-17III \\ File Number: 8-4-61 \\ SPR-2486 \\ In Cooperation with the \\ Indiana Department of Transportation \\ and the Federal Highway Administration
}

The contents of this report reflect the views of the authors, who are responsible for the facts and the accuracy of the data presented herein. The contents do not necessarily reflect the views or policies of the Indiana Department of Transportation. This report does not constitute a standard, specification, or regulation.

Purdue University

West Lafayette, IN 47907

March 2002 
TECHNICAL REPORT STANDARD TITLE PAGE

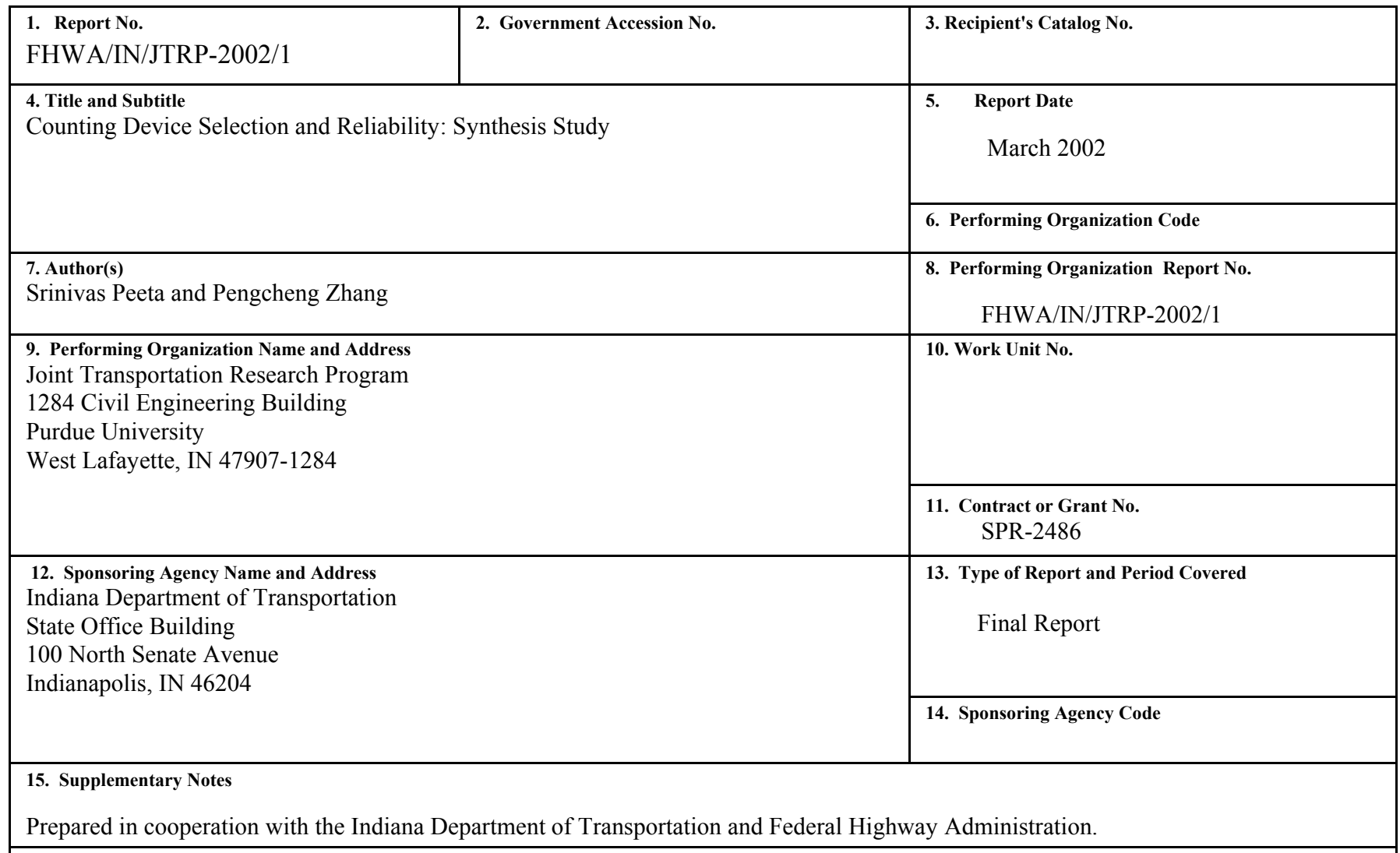

\section{Abstract}

Accuracy in traffic data detection is important for transportation operations and planning. Currently, inductive loop detectors are the most commonly used traffic counting devices in the field. New technologies are being developed to meet growing data counting and traffic surveillance needs. They include passive infrared, active infrared, passive magnetic, Doppler microwave, radar, passive acoustic, pulse and Doppler ultrasonic, and video image processor. However, the relatively recent, but widespread, emergence of these technologies and the consequent sparseness in information on their performance characteristics preclude traffic agencies from making informed choices in the selection of traffic counting devices. This study performs a comprehensive survey of the currently available traffic counting products in terms of functional capabilities, technological focus, performance characteristics, and user perspectives. It identifies the major selection criteria and ranks them in the order of importance based on user feedback from agencies in six U.S. states. A two-step filtering selection procedure is proposed to provide guidelines for traffic agencies to decide the type and make of devices that satisfy their data collection needs and the associated field environment. .

17. Key Words
traffic data, traffic counting device evaluation, intrusive and non-intrusive detectors, traffic counting device selection procedure, traffic counting device databases.
18. Distribution Statement

No restrictions. This document is available to the public through the National Technical Information Service, Springfield, VA 22161

\section{Security Classif. (of this report) \\ Unclassified}

20. Security Classif. (of this page)
Unclassified

21. No. of Pages
83

22. Price 


\section{ACKNOWLEDGEMENTS}

The authors acknowledge the assistance and feedback of the members of the study advisory committee: Shou Li, Lowell Basey, Lori Land, Ryan Gallagher, and Scott MacArthur of the Indiana Department of Transportation; and Dennis Lee of the Federal Highway Administration. The authors would also like to thank 24 survey respondents from the Departments of Transportation of California, Florida, Indiana, Minnesota, New York, and Texas, for sharing their experience and providing information and feedback on traffic counting devices in a user survey conducted for this study. The authors further acknowledge the contributions of undergraduate summer intern David Burkett to this study.

This project was funded by the Joint Transportation Research Program of Purdue University in cooperation with the Indiana Department of Transportation. We appreciate their support and assistance. 


\section{IMPLEMENTATION REPORT}

A set of databases consisting of intrusive and non-intrusive traffic counting devices was created as part of this study. Currently, 99 products from 32 vendors are recorded in the databases. Detailed information on each device is provided using a set of attributes that characterize the capabilities, parameters, features, and performance of the devices. Users can retrieve, update or extend device-related information, and select, sort or filter data to identify devices according to their needs and preferences. The databases can serve as a starting point for counting device selection procedure by state and local agencies. Selection criteria were identified and ranked in the order of importance based on a user survey. A two-step filtering selection procedure was proposed to identify appropriate counting devices based on user needs and field conditions. 


\section{TABLE OF CONTENTS}

Description Page

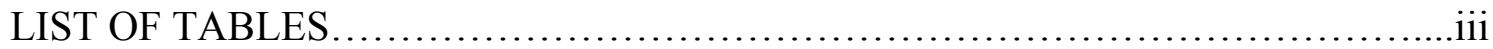

LIST OF FIGURES...........................................................

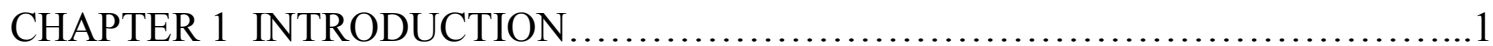

1.1 Motivation and Problem Description.......................................... 1

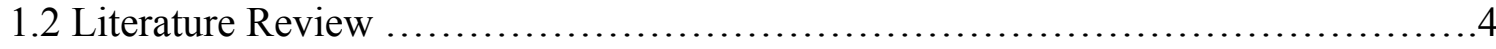

CHARPTER 2 REVIEW OF TRAFFIC COUNTING TECHNOLOGIES..............7

2.1 Non-intrusive Technologies ........................................... 7

2.1.1 Infrared (Active, Passive) ........................................... 7

2.1.2 Microwave (Doppler, Radar and Passive Millimeter) ......................8

2.1.3 Passive Acoustic.....................................................9

2.1.4 Ultrasonic (Pulse and Doppler) ................................... 9

2.1.5 Video Image Processors............................................9

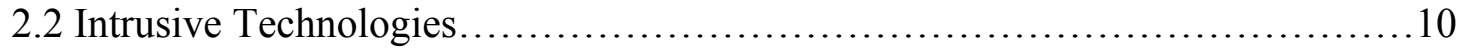

2.2.1 Magnetic (Passive) Detectors......................................11

2.2.2 Inductive Loop (Active Magnetic)................................. 11

2.2.3 Pneumatic Road Tube........................................... 12

CHAPTER 3 SELECTION CRITERIA AND PROCEDURE $\ldots \ldots \ldots \ldots \ldots \ldots \ldots \ldots \ldots . . . \ldots \ldots$

3.1 Selection Factors......................................................... 13

3.1.1 Device-related Factors ............................................. 13

3.1.1.1 Cost.......................................................13

3.1.1.2 Accuracy and Reliability...................................... 14

3.1.1.3 Ease of Installation and Maintenance...............................14

3.1.1.4 Portability and Storage............................................ 14

3.1.1.5 Ease of Data Retrieval............................................. 14

3.1.1.6 Data Type and Functional Capabilities..............................15

3.1.1.7 Amenability to Future Technological Advances......................15

3.1.1.8 Ease of Use and Personnel Training Needs........................15

3.1.2 Environment-related Factors ........................................ 15

3.1.2.1 Traffic Characteristics............................................. 16

3.1.2.2 Roadway Type............................................. 16

3.1.2.3 Installation Location and Position................................. 17

3.1.2.4 Weather Conditions............................................ 17

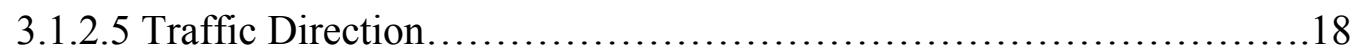

3.2 Selection Procedure ........................................................ 18

3.2.1 Two-step Filtering Selection Procedure............................... 18

3.2.2 Technology-specific Filtering....................................... 19

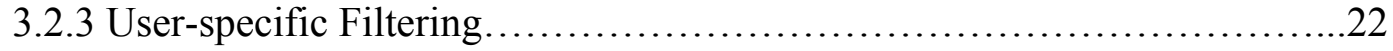




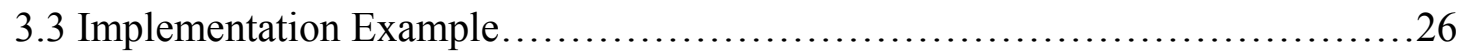

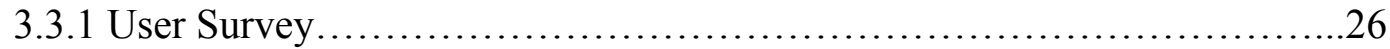

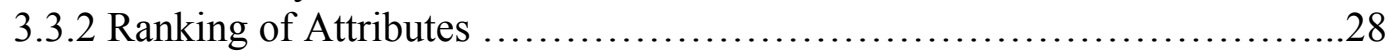

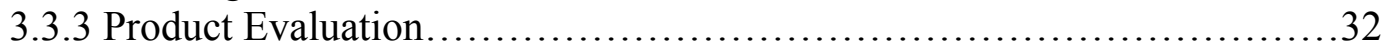

CHAPTER 4 TRAFFIC COUNTING DEVICE DATABASES.......................34

4.1 Descriptions of the Traffic Counting Device Databases............................34

4.1.1 Product Table.......................................................... 34

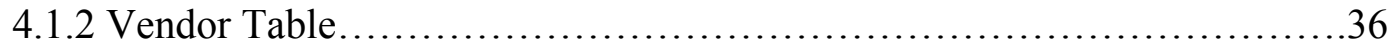

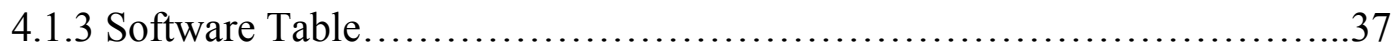

4.1.4 Product Evaluation Table..................................................37

4.2 Custom Queries and Relationships of Traffic Counting Device Databases.........37

4.3 Further Improvements to the Traffic Counting Device Databases..................39

CHAPTER 5 CONCLUSIONS.....................................................

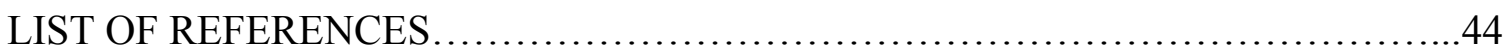

APPENDIX A: Product Information by Technology Category.......................47

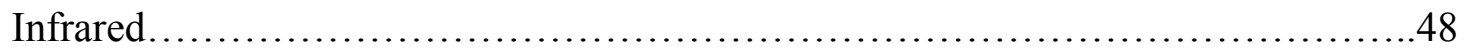

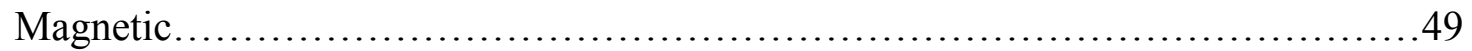

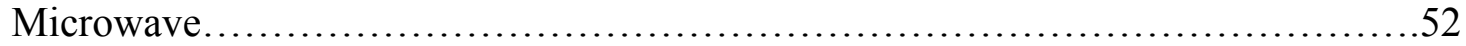

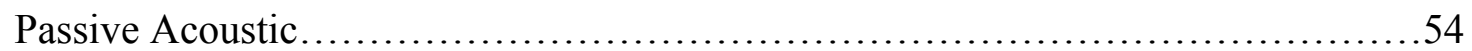

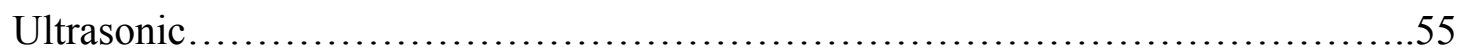

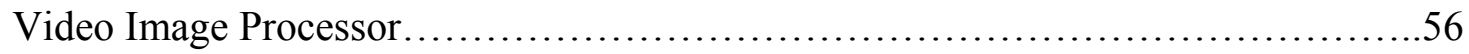

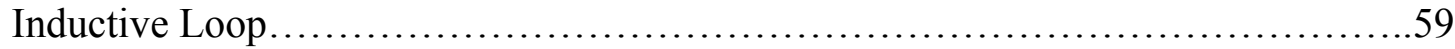

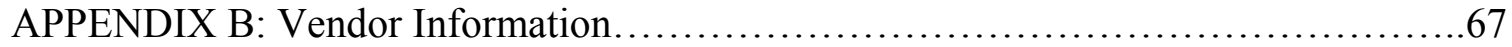

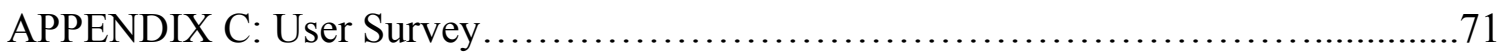

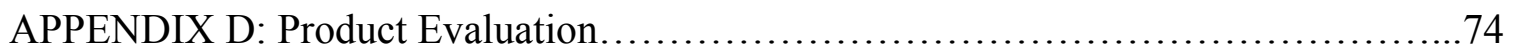

APPENDIX E: User Manual for the Databases in Microsoft Access ....................78

1 Basic Concepts of Microsoft Access.............................................79

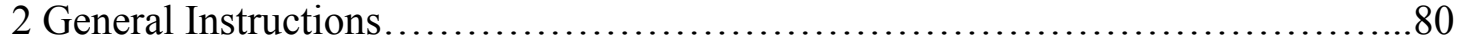




\section{LIST OF TABLES}

Table

Page

Table 3.1 Advantages and Disadvantages of Various Technologies...................23

Table 3.2 Recommended Technologies for Different Applications.....................25

Table 3.3 Ranking of Factors based on the Survey ............................... 30 


\section{LIST OF FIGURES}

Figure Page

Figure 3.1 Flow Chart of Two-step Filtering Selection Procedure.......................20

Figure 3.2 Ranking of Selection Factors........................................... 31

Figure 4.1 Example of Built-in Queries................................................

Figure 4.2 Relationships in Product Databases........................................39

Figure E-1 Example of Access Datasheet..............................................79

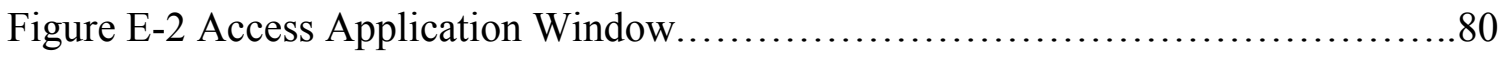

Figure E-3 Access Database Window.................................................. 81

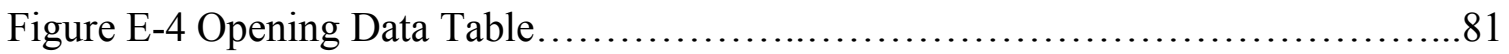




\section{CHAPTER 1 INTRODUCTION}

\subsection{Motivation and Problem Description}

The Intermodal Surface Transportation Efficiency Act of 1991 (ISTEA) stipulated requirements for state level Traffic Monitoring Systems (TMS) with an aim to systematize the collection, analysis and summary of person and vehicular data on public highways and streets. This mandate compounded by the growing need to more efficiently manage our existing transportation infrastructure is necessitating accurate, reliable and comprehensive traffic related data. Traffic data is used for a wide variety of purposes including traffic operation and control, geometric design, pavement design, highway- and land-use planning, resource allocation, and intelligent transportation systems (ITS) research and implementation.

In the context of ITS, traffic-related data needs from different roadway and environment types (scenarios) vary according to the transportation management phases (FHWA, 1995). For example, in the highway engineering management phase, short-term traffic counting and vehicle classification data are needed for highway geometry, pavement, and structural design. For the planning, legislation and safety phases, long- 
term traffic data is collected for infrastructure systems design, signal control systems design, and traffic demand forecasts. For traffic operation, control, and traveler information provision purposes, real-time data on speed, travel time, volume, density, and incidents is essential. Permanent (fixed position) and temporary (portable) devices are used to collect traffic data on various facilities such as highways, freeways, intersections, and city/town streets. Several terms, such as traffic counting device, monitoring device, surveillance device, measuring device, sensor, and detector, are used to name these devices. This taxonomy is typically exchangeable and is normally not differentiated in many cases, though trivial differences do exist in terms of the scenarios where they are used. For example, counting device is often used to refer to devices installed on freeways and/or highways to record the vehicle counts, while detector is typically used to refer to those detecting the presence of vehicles at intersections. However, these differences are not emphasized in the context of this study. We use the term "counting device" to generically refer to all devices that are permanently or temporarily installed in different scenarios to collect traffic data.

Traffic counts are generally classified into three categories according to the duration and area over which the counting equipments are deployed (FHWA, 1995): (i) a relatively limited continuous count program, (ii) an extensive coverage count program, and (iii) a flexible special needs program. Continuous counting locations have typically used the traditional automatic traffic recorders (ATR) permanently installed at various locations of the road network. They consist of an assembly of axle sensors and inductive loops of the bending plate or piezo-electric variety. The more extensive coverage count programs have normally used portable equipment. Traditionally these have included 
portable counters and pneumatic tubes that are installed across the roadway by mobile crews. However, there are some important drawbacks of using traditional intrusive counting devices. First, these devices are not easy to install and are often hazardous to the mobile crews especially under congested conditions. Second, being intrusive devices, they often cause some disruption of prevailing traffic flow even under moderate to light traffic conditions. Third, these equipment are known to malfunction under extreme temperature conditions. Fourth, the data types that these devices are able to detect are normally limited and cannot satisfy the increasing need of more sophisticated and comprehensive data for ITS applications. As a result, city and state agencies increasingly prefer newer and non-intrusive equipment based on radar, magnetic imaging, microwave and infrared technologies. Non-intrusive devices, by definition, are those that do not need to be installed in or on the pavement but can be mounted overhead, to the side, or beneath the pavement by "pushing" the device in from the shoulder (FHWA Study, 1997).

Notwithstanding the availability of these newer technologies for traffic monitoring and data collection, most state agencies lack a rigorous set of guidelines for the selection of traffic counting devices. This is primarily due to the relatively recent, though widespread, emergence of these technologies and the consequent sparseness in reliable information on their performance. Considering the wide range of currently available technologies, a uniform set of guidelines based on a series of criteria including cost, accuracy, reliability, durability, flexibility, and ease of use can be invaluable to system operators.

This study performs an extensive survey of available intrusive and non-intrusive counting technologies and develops a broad set of selection criteria which can be used for 
traffic measuring device selection. The survey includes a detailed literature review of existing evaluation techniques. It also includes e-mail surveys of some state/local agencies from six states: California, Florida, Indiana, Minnesota, New York, and Texas. The surveys record their experience with traffic counting devices and identify additional practical issues. In addition, the study presents comprehensive product information to compare traffic measuring devices.

\subsection{Literature Review}

A few recent studies on non-intrusive and intrusive traffic counting devices have shown wide variations in the performance of these technologies under varying conditions of traffic, weather, and geometry. Some of these studies (Faghri et al., 1996) are localized in that their conclusions apply only to a specific region or to specific traffic conditions. Some others have either neglected important emerging technologies (Hallenbeck, 1985) or draw product specific insights that cannot be extrapolated to the technology in use (FHWA Study, 1997).

Hughes (1993) conducted an extensive survey of vehicle detector technologies available up to 1993. It collected information on intrusive and non-intrusive detectors, including video image, ultrasonic, sonic, infrared, and microwave radar. A major component of the study was the collection of manufacturer specification sheets for over 80 traffic devices. These specification sheets provided detailed information on the detectors, in terms of functions, features, operating conditions, parameters, installation/operation instructions, data communication, and other related technical data. A primary drawback of the study is that few analyses, evaluations, and/or comments were

provided on the performance of the different technologies and/or devices. Another 
drawback is that detector information from the vendor specification sheets was not summarized or classified, precluding retrieval of useful information and/or efficient product comparison. The third drawback is the limited discussion on non-intrusive devices, given the sparse installation of such devices at the time of the study. Over $80 \%$ of the total devices listed were inductive loop detectors or inductive loop vehicle identification systems. The fourth drawback is that no selection criteria and/or selection procedure were provided. However, some simple criteria, rather than a generic user selection procedure, were used to select sample devices for a further field test. The five criteria used were availability, demonstrated capability, compatibility with controllers in place at the field test locations, representative of current technology, and vendor support.

Another study on traffic counting devices was conducted for the Federal Highway Administration (FHWA Study, 1997) by the Minnesota Department of Transportation, the Minnesota Guidestar Program, and the SRF Consulting Group. Its main objective was to provide practitioners with useful information on the performance of emerging nonintrusive technologies, and some specific devices within each technology category. It focused on passive infrared, active infrared, passive magnetic, Doppler microwave, radar, passive acoustic, pulse ultrasonic, and video image detector technologies. One or two representative products were selected from each technology category, and tested on freeways as well as traffic intersections to examine the performance of these devices under different situations. The capabilities and limitations were analyzed under various conditions, and basic information on the suitability of a technology for various data collection needs was provided. However, akin to the Hughes study, it does not provide selection criteria or procedures for users with specific functional needs. Another potential 
shortcoming is that the test used an inductive loop as the benchmark to test the counting accuracy of each non-intrusive detector. This presumes that the inductive loop is $100 \%$ accurate under all circumstances, which is not necessarily true.

An on-going FHWA "Vehicle Detector Clearinghouse" (Mimbela and Klein, 2000) pooled-fund project treats the vehicle detection and surveillance technologies as integral parts of ITS. The project includes an extensive product database stored in Microsoft Excel format, called the Clearinghouse database. Products are classified into different categories including inductive loops, magnetometers, micro-loop probes, pneumatic road tubes, piezoelectric cables, microwave radar, infrared, ultrasonic, acoustic, and video image. For each product, information on vendor contacts, software version, general description, sensor installation, maximum number of lanes monitored simultaneously, product capabilities/functions, recommended applications, data output methods/formats, and states currently using the equipment, are provided. Currently, there are approximately 80 products recorded in the Clearinghouse database. Akin to the previous efforts, no selection criteria or procedure are provided though the advantages and disadvantages of all technologies are summarized and compared.

There have been some past studies in Indiana related to traffic detector evaluation. Krogmeier et al. (1996) evaluate the performance of various non-intrusive devices on the Borman Expressway (I-80/94). Hypothesis-based procedures were used to analyze their reliability. Grenard et al. (2001) evaluate the performance of selected video detection systems at signalized intersections. 


\section{CHAPTER 2 REVIEW OF TRAFFIC COUNTING TECHNOLOGIES}

As the first step in the development of guidelines for traffic counting device selection, an extensive review of available detection technologies was conducted. It includes intrusive and non-intrusive detection technologies, though the non-intrusive detectors are emphasized to ensure that state-of-the-art technologies are considered in the evaluation process. The survey suggests that information on the performance of emerging detection technologies is, currently, sparse and difficult to obtain.

\subsection{Non-intrusive Technologies}

Non-intrusive technologies represent the emerging detection technologies, and are so labeled because they are not physically present on the pavement. Hence, they do not interfere with traffic flow, both for operational and maintenance purposes.

\subsubsection{Infrared (Active, Passive)}

Infrared devices are available for overhead mounting to view approaching or departing traffic from a side-looking configuration. Passive infrared devices detect the presence of vehicles by comparing the infrared energy naturally emanating from the road surface with the change in energy caused by the presence of a vehicle. Since the roadway may generate either more or less radiation than a vehicle depending on the season, the contrast in heat energy is detected. Active infrared devices detect the presence of vehicles by emitting a low-energy laser beam(s) at the road surface and measuring the time for the reflected signal to return to the device. Passive infrared detectors provide data on vehicle presence at traffic signals, volume counts, vehicle length, and queue measurements. Active infrared detectors are capable of providing speed measurements in addition to the 
data captured by passive infrared devices. Previous studies (Bahler et al., 1998) have reported infrared technology as being suitable for monitoring traffic in urban areas, but performance varies under severe weather conditions.

The main advantage of infrared devices is that they can cover multiple lanes simultaneously. Under normal weather conditions, they can accurately measure vehicle position, speed, and class. The main disadvantage is the lack of accuracy under weather conditions such as rain and fog because the associated changes in air conditions may influence the reflection of the infrared beam.

\subsubsection{Microwave (Doppler, Radar and Passive Millimeter)}

Microwave detectors are generally mounted either directly overhead or on the side of the roadway. Doppler microwave devices transmit low-energy microwave radiation at a target area on the pavement and then analyze the signal reflected back to the detector. These devices can be used for volume and speed measurements. Radar devices have the ability to sense the presence of stationary vehicles and to sense multiple zones through their range-finding ability. A third type of microwave detector, passive millimeter, operates at a shorter wavelength than the other microwave devices. It detects the electromagnetic energy in the millimeter radiation frequencies from all objects in the target area.

Analogous to infrared devices, microwave devices can cover multiple lanes and generally perform well at freeway sites. Another advantage of this technology class is that they are normally insensitive to bad weather. However, they are known to fail for urban traffic especially at intersections with complex geometries (Bahler et al., 1998). Also, the usage of microwave is limited because the antenna beam width and transmitted 
waveform must be suitable for the application. Besides, Doppler sensors cannot detect stopped vehicles.

\subsubsection{Passive Acoustic}

Passive acoustic devices consist of an array of microphones aimed at the traffic stream. They are passive in that they seek the sound energy of passing vehicles. Mounted from a side-fire position, they can be used to obtain volume, speed, occupancy, and classification information. They allow multiple lane operation and are easy to install. However, they tend to undercount at low temperatures and under snowy conditions (Bahler et al., 1998).

\subsubsection{Ultrasonic (Pulse and Doppler)}

Pulse devices emit pulses of ultrasonic sound energy and measure the time for the signal to return to the device. Doppler ultrasonic devices emit a continuous ultrasonic signal and utilize the Doppler principle to measure the shift in the reflected signal.

Mounted either directly overhead or from a side-fire position, these devices are able to provide surveillance on multiple lanes and are known to provide fairly accurate counts. However, some environmental conditions such as temperature changes and extreme air turbulence can affect the performance of these detectors. This situation is mitigated by the employment of temperature compensation algorithms in some models. Another weakness of this class is that large pulse repetition periods may degrade occupancy measurements on freeways for vehicles traveling at moderate to high speeds.

\subsubsection{Video Image Processor}

Video devices use a microprocessor to analyze the video image input from a video camera. Two basic analysis techniques that are used are: (i) tripline, and (ii) tracking. 
Tripline techniques monitor specific zones on the video image to detect the presence of a vehicle. Video tracking techniques employ algorithms to identify and track vehicles as they pass through the field of view. Video detection devices generally use one or both of these techniques.

The primary advantage of video detection is the wide range of data it can provide. Apart from the usual data on volume, presence, occupancy, density, speed and classification, other data such as vehicle identification, incident detection, and origindestination information can be obtained. At present, video detection techniques are highly reliable for freeway sites but less reliable for urban areas. In addition, several environmental factors such as lighting, wind and precipitation are known to affect video detection performance. Inclement weather, shadows, vehicle projection into adjacent lanes, occlusion, day-to-night transition, vehicle/road contrast, shaking of camera caused by wind, and water, salt, dirt, grime, icicles, and cobwebs on camera lens are problematic. Thus, a video image detector requires more maintenance efforts to assure reasonably good performance. Besides, cameras need to be typically mounted at heights of 50 to 60 feet, which restricts the flexibility of the use of these products. Another issue is the comparatively high cost when more detection is needed in a zone.

\subsection{Intrusive Technologies}

Intrusive technologies interfere with traffic flow for their installation and maintenance. They represent the traditional detection technologies, and are predominantly employed as counting devices currently. 


\subsubsection{Magnetic (Passive) Detectors}

Passive magnetic devices measure the change in the earth's magnetic flux created when a vehicle passes through a detection zone. Due to the mechanism used to detect vehicles, these devices are normally installed under the pavement. Though they are capable of giving accurate volume counts, they are intrusive and are known to be affected by extreme weather conditions. Passive magnetic devices cannot detect stopped vehicles.

\subsubsection{Inductive Loop (Active Magnetic)}

Active magnetic devices, such as inductive loops, apply a small electric current to a coil of wires and detect the change in inductance caused by the passage of a vehicle. The inductive loop detector is the most commonly used traffic counting device. It usually consists of one or more turns of insulated wire buried in a shallow saw-cut in the roadway, a lead-in cable that runs from a roadside pull box to the controller cabinet, and an electronics unit located in the controller cabinet. The wire loop is excited with signals whose frequencies range from $10 \mathrm{KHz}$ to $50 \mathrm{KHz}$, and functions as an inductive element in conjunction with the electronics unit. When a vehicle stops on or passes over the loop, the inductance of the loop is decreased. The decreased inductance increases the oscillation frequency and causes the electronics unit to send a pulse to the controller, indicating the presence or passage of a vehicle.

The technology of inductive loop is very mature and is proved to have good performance on detecting volume, presence, occupancy, speed, headway and gap. The cost of inductive loop sensors is low compared to that of non-intrusive sensors. The drawbacks of inductive loop detectors are the typical drawbacks of intrusive devices. They include the interruption of traffic during installation, the damage to the road 
surface, and safety issues for installation personnel. Also, detector failures have been observed under poor pavement surface conditions and due to the penetration of water into the saw-cut under rain. In addition, resurfacing of roadways and utility repairs may entail the need to reinstall the sensors.

\subsubsection{Pneumatic Road Tube}

The pneumatic road tube sensor sends a burst of air pressure along a rubber tube when a vehicle's tires pass over the tube. The pulse of air pressure closes an air switch, producing an electrical signal that is transmitted to a counter or analysis software.

The pneumatic road tube is easy to install, and has good portability both for permanent and temporary data recording. It is a low cost device and is simple to maintain. But the accuracy of such detectors is low when truck and bus volumes are high because of the physical characteristics of these vehicles. Also, the device is easily influenced by weather. 


\section{CHAPTER 3 SELECTION CRITERIA AND PROCEDURE}

Over the past decade, several traffic counting devices of different technologies have become commercially available. A common concern of many state and local transportation agencies is the type of technology and the characteristics of the devices to consider while upgrading current traffic systems or building new ones. However, systematic methods to select traffic counting devices have received little attention in the past. In this chapter, a systematic selection procedure is proposed, and examples of implementation are discussed.

\subsection{Selection Factors}

Several factors need to be considered when selecting traffic counting devices. They can be categorized into two main classes: device-related factors and environment-related factors.

\subsubsection{Device-related Factors}

Several device-related aspects influence the selection of traffic counting devices. They range from budget limits to data issues to ease of use.

\subsubsection{Cost}

An equitable cost comparison between the different device alternatives should consider the application for which they are intended. For example, although the cost of ultrasonic or microwave detectors may be much lower than that of a video image processor, the total costs of multiple microwave or ultrasonic detectors may far exceed that of a video image processor based setup for the same amount of data. 


\subsubsection{Accuracy and Reliability}

Accuracy and reliability are the basic requirements for any counting device. The accuracy is typically measured by the average percentage of overcounted or undercounted vehicles compared to the actual number of vehicles passing or present. Reliability is a proxy for how stable the counter performs. For some devices, while the average counting performance is good, they may constantly miss or double-count vehicles so that the missing and double-counting eliminate each other. For some others, the performance varies dramatically under different external conditions or during different periods in their life span. These devices are considered unreliable. A critical factor that affects the accuracy and reliability of traffic counting devices is the climatic conditions of the region. Past studies (FHWA Study, 1997) have shown that different devices may compare differently under different weather and traffic conditions.

\subsubsection{Ease of Installation and Maintenance}

Many agencies cite ease of installation and maintenance as the primary reasons for rejecting some detection technologies. It is desirable that the employed device be mountable overhead or from a side-fire position to avoid cutting into the pavement.

\subsubsection{Portability and Storage}

Temporary data collection for a specific time period is an important data collection category. In this context, the portability and storage of the devices is a key issue.

\subsubsection{Ease of Data Retrieval}

Compatibility of the traffic counting device output with existing data collection programs is desirable. The data should be easily downloadable into a popular database format. With the recent emergence of ITS, data obtained from these detectors are also being used for 
real-time traffic operation and control. Therefore, it is also desirable that the technology used be able to provide data to a central location in a fast and reliable manner.

\subsubsection{Data Type and Functional Capabilities}

A wide range of data (traffic flow, weather conditions, road surface conditions, etc.) can be measured using different counting devices. This requires the evaluation of the amount and versatility of data that can be collected by a traffic counting device relative to its other characteristics (such as cost, accuracy, ease of installation, etc.) and the functional needs of the traffic site.

\subsubsection{Amenability to Future Technological Advances}

The traffic detection technology arena has been undergoing a rapid evolution over the past few years. One aspect that needs to be addressed in this context is the evaluation of the various devices in terms of their adaptability and amenability to future advances in detection and data retrieval technologies.

\subsubsection{Ease of Use and Personnel Training Needs}

In the absence of specific standards, a key issue with the use of counting devices manufactured by different vendors is the need for training field personnel. This is because that each vendor may have counting devices characterized by unique technology, features, and software. This also raises the issue of ease-of-use of a certain product.

\subsubsection{Environment-related Factors}

A FHWA study (FHWA Study, 1997) indicates that the performance of different intrusive and non-intrusive technologies depends explicitly on several environmentrelated factors including the prevailing weather and traffic conditions. When selecting 
counting devices, these factors should be considered based on the specific conditions in a region. The factors are:

\subsubsection{Traffic Characteristics}

The performance of many devices is influenced by the traffic characteristics being detected. These characteristics include vehicle speeds, congestion levels, and vehicle class percentages. For instance, the passive acoustic and microwave detectors are observed to consistently undercount vehicles under high congestion levels (FHWA Study, 1997) because continuous traffic flows with very small headways may have the same reflection character as a single vehicle. Thereby, they are treated as a unit by these devices. Some pulse ultrasonic devices tend to miss vehicles with high speeds as these devices dismiss ultrasonic waves of certain frequencies. When the frequency is larger than the time taken for the vehicle to pass the detection zone, potential missed counts may occur. Some video image process devices double count slow-moving vehicles due to flaws in the image processing logic. The percentages of vehicles of different classes may also influence detection performance. Passive infrared, radar and pulse ultrasonic devices may overcount trucks and buses because multiple reflections from a single vehicle may be received. Trucks and buses may also be double counted because they may intrude into neighboring lanes due to the size of these vehicles. Thus, these devices may perform unevenly when high percentages of trucks and buses are present in the traffic stream.

\subsubsection{Roadway Type}

The performance of some devices varies on different types of roadways as different types of roadways have their own flow and geometry characteristics. For instance, Doppler microwave technology can detect freeway traffic well. However, it performs poorly at 
intersections where the associated devices have been observed to undercount or overcount vehicles (FHWA Study, 1997). Some pulse ultrasonic devices overcount between 10 and 30 percent at intersections, though they perform well on freeways.

\subsubsection{Installation Location and Position}

The installation location affects the performance of some counting devices. Some passive acoustic devices perform significantly better when located at the median pole site than on bridges (FHWA Study, 1997). For some pulse ultrasonic detectors, overhead mount with the detector aimed straight down is preferred because this offers a perpendicular vehicle surface for reflecting the ultrasonic signal.

Some devices are very sensitive to the position of sensors or cameras. Positions and angles need to be carefully adjusted and calibrated to obtain optimal performance. For example, the mounting height is an important factor vis-à-vis accuracy for passive infrared detectors.

\subsubsection{Weather Conditions}

Inclement weather affects the accuracy of many traffic counting devices. Also, different weather conditions have different impacts on various technologies. Hence, the local climate is critical to the selection of a traffic counting device. Snowfall, rain and freezing rain are correlated with either undercounting or overcounting (FHWA Study, 1997) for many counters. Snow and rain have been observed to affect passive magnetic device performance. This is most likely due to water entering the device, and does not reflect a limitation of the technology itself. A correlation was found between low temperatures and undercounting for passive acoustic devices. The presence of snow on the roadway is also correlated with undercounting. Snow or rain caught by video image cameras may be 
processed as vehicles thus lead to overcounting, and a heavy fog may cause total failure of such devices.

\subsubsection{Traffic Direction}

Some passive infrared devices are designed to face oncoming traffic. These devices cannot be used to detect departing traffic. By contrast, some Doppler microwave devices were observed to detect departing vehicles more accurately (FHWA Study, 1997). However, they overcount traffic in the oncoming direction.

\subsection{Selection Procedure}

Based on the selection criteria described in the previous section, a two-step procedure is proposed to select traffic counting devices.

\subsubsection{Two-step Filtering Selection Procedure}

The selection of a specific traffic counting device depends on the functional capabilities of the associated technology vis-à-vis the field conditions, and user data needs and constraints. Devices in a technology category typically have some common characteristics such as type of data detected, installation position, detection accuracy and reliability, cost, and operation/maintenance requirements. As described in chapter 2, each technology can only collect certain types of traffic data, and is sensitive to the type of roadway (such as intersection or freeway) and congestion conditions. Also, the performance of some technologies is affected by weather or climate conditions. Hence, the technology-related filter uses the following criteria to select the technology alternatives for the selection of the traffic counting device: data needs and purpose, weather/climate conditions, traffic conditions, and roadway type. This is illustrated further in Figure 3.1 which details the two-step selection procedure. The technology- 
specific product information in Appendix A is filtered using Microsoft Access features for this purpose. The vendor information of corresponding products is listed in Appendix B.

The second step of the selection procedure uses user-specific filtering criteria to identify candidate counting device products. The criteria include detection accuracy and reliability requirements, budget constraints, personnel training requirements, and data format and processing capabilities.

Within each step, the criteria can further be ranked by order of importance as identified by the user. The Microsoft Access based database developed in the study enables this capability.

\subsubsection{Technology-specific Filtering}

In the first step of the selection procedure, traffic counting devices in the candidate database are filtered based on user data collection needs, roadway type, field traffic conditions, and the climatic conditions of the region.

The inductive loop detector is the most commonly used counting device. The data detected by these devices typically includes vehicle passage, presence, count, and occupancy. Vehicle speed can be measured by using more than one detector at various locations. Vehicle classification is supported by newer inductive loop detector models.

Passive magnetic detectors mainly refer to the two-axis fluxgate magnetometer. They detect most of the data that can be detected by inductive loop detectors; however, they normally fail to detect stopped vehicles since they require the vehicles to be moving to generate a magnetic field. 


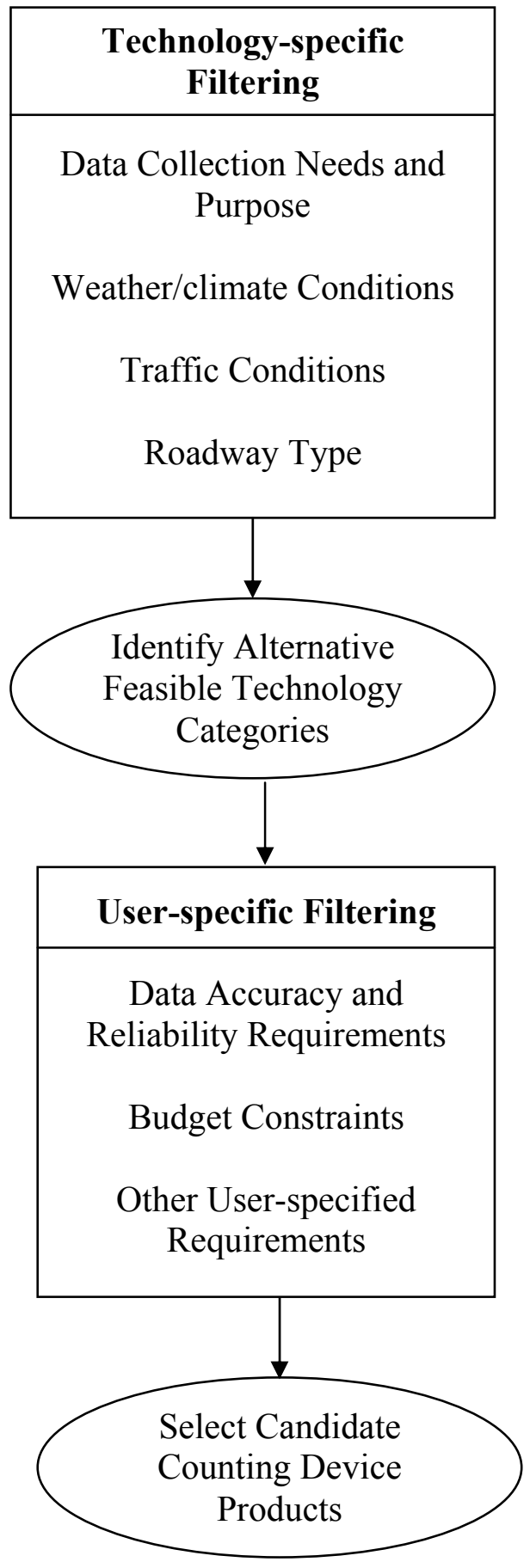

Figure 3.1 Flow Chart of Two-step Filtering Selection Procedure 
The pneumatic road tube is commonly used for short-term traffic counting and vehicle classification. Some models gather data to calculate vehicle gaps, intersection delay, stop sign delay, saturation flow rate, speed, and travel time by employing algorithms.

Active infrared sensors provide vehicle presence, count, volume, speed, length assessment, queue, and occupancy. Some modern laser sensors produce two-dimensional or three-dimensional images of vehicles which enables vehicle classification. Passive infrared devices measure speed and vehicle length as well as other conventional data such as volume and lane occupancy.

Microwave sensors (Doppler, Radar, and Passive Millimeter) can be mounted over lanes or other locations to measure approaching or departing traffic data in multiple lanes. The data types measured by microwave sensors depend on the waveform used to transmit the microwave energy. The Doppler microwave detector detects vehicle passage, speed, volume, count, presence, occupancy, and classification.

Passive acoustic detectors can detect passage, presence, and speed of vehicles. The speed of a detected vehicle is determined using an algorithm based on the average vehicle length. The vehicle presence is detected through an optically isolated semiconductor.

In ultrasonic detectors, pulse energy transmitted at a certain frequency is used to calculate the vehicle speed. However, stopped or slow vehicles may be ignored. Other data that can be detected include count and occupancy.

One video image processor can detect traffic conditions at the entire intersection or over a long freeway segment. Hence, it can replace several inductive loop detectors. 
Some video image processor systems can process data from several video cameras. Video image processors can measure several data types including vehicle counts, vehicle length, presence, classification, occupancy, and speed. Hence, data can be obtained by vehicle classes. Some newer models can identify the vehicle registration plate numbers.

The counting devices in each technology category have some common advantages and disadvantages. Table 3.1 summarizes the advantages and disadvantages of each technology category. Table 3.2 identifies recommended technologies for various applications.

\subsubsection{User-specific Filtering}

The second step of the selection procedure is user-specific filtering. After the selection of candidate technologies, the feasible set of potential devices needs to be analyzed using user criteria. User-specific filtering can be divided into 3 steps.

In the first step, a set of selection criteria are decided according to the data needs and environmental/traffic conditions. As described in Section 3.1, the possible selection factors include both device-related and environment-related factors. However, depending on the actual application scenario, a user may consider different factors when selecting products. For example, some users emphasize the price, maintenance cost, and personnel training requirements, while other users pursue the quality of data and emphasize data versatility, accuracy, and the reliability of the devices irrespective of the price.

In the second step, the relative weight of each criterion in the selection procedure is decided. This is done by evaluating the specific user objectives. Based on the user survey conducted in this study, a set of recommended relative weight values for selection factors is proposed in Section 3.3. 
Table 3.1 Advantages and Disadvantages of Various Technology Categories (based on Mimbela and Klein, 2000)

\begin{tabular}{|c|c|c|c|}
\hline Technology & Advantages & Disadvantages & Performance \\
\hline $\begin{array}{l}\text { Inductive } \\
\text { Loops }\end{array}$ & $\begin{array}{l}\text { - Mature and well- } \\
\text { developed } \\
\text { - Well-known to engineers } \\
\text { - Low cost } \\
\text { - Basic traffic data } \\
\text { - Accurate and reliable }\end{array}$ & $\begin{array}{l}\text { - Installation deteriorates } \\
\text { pavement } \\
\text { - Poor performance under } \\
\text { bad pavement conditions } \\
\text { - Disturbs traffic } \\
\text { - Installation personnel } \\
\text { safety issues } \\
\text { - Requires multiple detectors } \\
\text { for a location } \\
\text { - Water penetration affects } \\
\text { performance }\end{array}$ & $\begin{array}{l}\text { Potentially good } \\
\text { performance on } \\
\text { intersections } \\
\text { and freeways }\end{array}$ \\
\hline $\begin{array}{l}\text { Passive } \\
\text { Magnetic }\end{array}$ & - Accurate and reliable & $\begin{array}{l}\text { - Extensive effort for } \\
\text { installation } \\
\text { - Some models need } \\
\text { pavement cutting } \\
\text { - Disturbs traffic } \\
\text { - Cannot detect stopped } \\
\text { vehicles }\end{array}$ & $\begin{array}{l}\text { Potentially good } \\
\text { performance for } \\
\text { intersections } \\
\text { and freeways }\end{array}$ \\
\hline Microwave & $\begin{array}{l}\text { - Flexible installation } \\
\text { position } \\
\text { - Generally insensitive to } \\
\text { inclement weather } \\
\text { - Single detector sufficient } \\
\text { to measure speed } \\
\text { - Multiple lane coverage }\end{array}$ & $\begin{array}{l}\text { - Restriction of antenna } \\
\text { beam bandwidth } \\
\text { - Doppler sensors cannot } \\
\text { detect stopped vehicles }\end{array}$ & $\begin{array}{l}\text { Potentially good } \\
\text { performance on } \\
\text { freeways }\end{array}$ \\
\hline
\end{tabular}


Table 3.1 Advantages and Disadvantages of Various Technology Categories (continued)

\begin{tabular}{|c|c|c|c|}
\hline Technology & Advantages & Disadvantages & Performance \\
\hline Infrared & $\begin{array}{l}\text { - Accurate measurement of } \\
\text { vehicle position, speed } \\
\text { and vehicle class } \\
\text { - Multiple lane coverage }\end{array}$ & $\begin{array}{l}\text { - Active detector may be } \\
\text { affected by fog or snow } \\
\text { - Sensitivity to vehicles } \\
\text { reduces in rain and fog for } \\
\text { passive detector }\end{array}$ & $\begin{array}{l}\text { Potentially good } \\
\text { performance on } \\
\text { intersections } \\
\text { and freeways }\end{array}$ \\
\hline Ultrasonic & - Multiple lane coverage & $\begin{array}{l}\text { - Some environmental } \\
\text { conditions such as } \\
\text { temperature change and } \\
\text { extreme air turbulence } \\
\text { affect performance } \\
\text { - Problems on freeways } \\
\text { when vehicles travel at } \\
\text { moderate to high speeds }\end{array}$ & $\begin{array}{l}\text { Potentially good } \\
\text { on intersections } \\
\text { and freeways }\end{array}$ \\
\hline Acoustic & - Multiple lane coverage & $\begin{array}{l}\text { - Cold temperature affects } \\
\text { accuracy } \\
\text { - Some models have poor } \\
\text { performance for slow } \\
\text { traffic }\end{array}$ & $\begin{array}{l}\text { Moderate } \\
\text { potential on } \\
\text { intersections } \\
\text { and freeways }\end{array}$ \\
\hline $\begin{array}{l}\text { Video } \\
\text { Image } \\
\text { Processor }\end{array}$ & $\begin{array}{l}\text { - Multiple lane coverage } \\
\text { - Rich data types } \\
\text { - Multi-media data }\end{array}$ & $\begin{array}{l}\text { - Affected by inclement } \\
\text { weather, shadows, vehicle } \\
\text { projection, and time of day }\end{array}$ & $\begin{array}{l}\text { Moderate } \\
\text { potential on } \\
\text { intersections } \\
\text { and freeways }\end{array}$ \\
\hline
\end{tabular}


Table 3.2 Recommended Technologies for Different Applications (based on Klein, 2002)

\begin{tabular}{|c|c|c|}
\hline Applications & Assumptions & Recommended Technologies \\
\hline $\begin{array}{l}\text { - Signalized } \\
\text { intersection control }\end{array}$ & $\begin{array}{l}\text { - Detect stopped vehicles } \\
\text { - Weather not a major factor }\end{array}$ & $\begin{array}{l}\text { - Microwave radar } \\
\text { - Passive infrared } \\
\text { - Laser radar } \\
\text { - Ultrasound } \\
\text { - Video image processor }\end{array}$ \\
\hline $\begin{array}{l}\text { - Signalized } \\
\text { intersection } \\
\text { control }\end{array}$ & $\begin{array}{l}\text { - Detect stopped vehicles } \\
\text { - Inclement weather }\end{array}$ & $\begin{array}{l}\text { - } \text { Microwave radar } \\
\text { - Ultrasound } \\
\text { - Long-wavelength imaging } \\
\text { infrared video processor }\end{array}$ \\
\hline $\begin{array}{l}\text { - Signalized } \\
\text { intersection } \\
\text { control }\end{array}$ & $\begin{array}{l}\text { - Detection of stopped vehicles not } \\
\text { required } \\
\text { - Inclement weather }\end{array}$ & $\begin{array}{l}\text { - } \text { Microwave radar } \\
\text { - Doppler microwave } \\
\text { detector } \\
\text { - Ultrasound } \\
\text { - Long-wavelength imaging } \\
\text { infrared video processor }\end{array}$ \\
\hline $\begin{array}{l}\text { - Real-time adaptive } \\
\text { signal control }\end{array}$ & $\begin{array}{l}\text { - Desirable for detector footprint to } \\
\text { emulate a 6-ft by 6-ft inductive } \\
\text { loop } \\
\text { - Side-mounting capability }\end{array}$ & $\begin{array}{l}\text { - Video image processor } \\
\text { - Microwave radar } \\
\text { Passive infrared (with } \\
\text { suitable aperture } \\
\text { beamwidth) }\end{array}$ \\
\hline $\begin{array}{l}\text { - Vehicle counting } \\
\text { (surface street or } \\
\text { freeway) }\end{array}$ & $\begin{array}{l}\text { - Detect and count vehicles } \\
\text { traveling at speeds greater than } 2 \\
\text { to } 3 \text { miles/hour }\end{array}$ & $\begin{array}{l}\text { - Microwave radar } \\
\text { - Doppler microwave } \\
\text { - Passive infrared } \\
\text { - Laser radar } \\
\text { - Ultrasound } \\
\text { - Video image processor }\end{array}$ \\
\hline
\end{tabular}


Table 3.2 Recommended Technologies for Different Applications (continued)

\begin{tabular}{|c|c|c|}
\hline Applications & Assumptions & Recommended Technologies \\
\hline $\begin{array}{l}\text { - Vehicle speed } \\
\text { measurement }\end{array}$ & $\begin{array}{l}\text { - Detect and count vehicles } \\
\text { traveling at speeds greater than } 2 \\
\text { to } 3 \text { miles/hour }\end{array}$ & $\begin{array}{l}\text { - } \text { Microwave radar } \\
\text { - Doppler microwave } \\
\text { detector } \\
\text { - Laser radar } \\
\text { - Video image processor }\end{array}$ \\
\hline $\begin{array}{l}\text { - Vehicle } \\
\text { classification }\end{array}$ & - By length & $\begin{array}{l}\text { - Video image processor } \\
\text { - Laser radar }\end{array}$ \\
\hline $\begin{array}{l}\text { - Vehicle } \\
\text { classification }\end{array}$ & - By profile & - Laser radar \\
\hline
\end{tabular}

The third step involves collecting the relevant attribute data for each product. This is difficult because the product information specified varies across vendors. Also, some attributes such as accuracy, reliability, ease of installation, and personnel training requirements, are not easily quantifiable, making product comparison relatively difficult.

\subsection{Implementation Example}

As an example implementation of the two-step selection procedure, a survey was conducted to elicit user opinions on selection factors, criteria weights, data needs, and product evaluation.

\subsubsection{User Survey}

As shown in Appendix C, this survey consists of four sets of questions. The first set collects information on the respondents including employer, position, work type, and years of experience with traffic data collection/traffic counting devices. The second set of 
questions requires the respondents to rate the importance of different factors when purchasing traffic counting devices. The factors specified are: price, accuracy, durability, reliability, portability, ease of data retrieval, ease of installation, functionality, personnel training needs, and maintenance requirements. The third question set seeks information on the type of traffic data needed by the respondents for their work. The last question set asks respondents to evaluate the traffic counting devices being used in their state or district. For each product, the overall performance, accuracy, reliability, lifecycle costs, training requirements, ease of installation/maintenance, and data collection ability are scored using grades A, B, C, D and E. Here, "A" represents the most favorable grade and "E" represents the least favorable one.

The survey was sent using e-mail to personnel who responsible for traffic data collection in various districts or regional subdivisions of the departments of transportation in six states including California, Florida, Indiana, Minnesota, New York, and Texas. These states were chosen either because they were involved in previous efforts on traffic counting device evaluations, or because they are representative of the various U.S. geographical regions. 47 e-mails were sent and 24 responses were obtained through e-mail or regular mail. Of these, 20 responses were complete and 4 were partly incomplete.

The state-wise break-up of the 24 respondents is as follows: California (5), Florida (4), Indiana (3), Minnesota (4), New York (3), and Texas (5). 18 out of the 24 respondents are involved in traffic operations. The average work experience of the respondents in traffic data collection and/or traffic counting devices is 8 years. 


\subsubsection{Ranking of Attributes}

As stated in Section 3.2, a key step in the traffic counting device selection process is the identification of the relative importance of each factor that needs to be considered. The respondents were asked to rate the ten factors listed in the survey. A rank of 1 implied most important, and 10 implied least important. Table 3.3 shows the associated results based on the 20 complete responses. Based on the survey, the average relative importance of the various factors is listed below in a descending order: accuracy, reliability, durability, functionality, data retrieval, ease of installation, price, portability, maintenance needs, and personnel training needs. This is further highlighted in Figure 3.2.

Not surprisingly, the most important factor identified in the survey is the data accuracy. This is because constant overcounting or undercounting seriously affects the effectiveness of an associated strategy for traffic operations. For example, failure to detect vehicle presence may lead to extra delay for certain directions. Overcounting may cause unnecessary budget allocations for a less congested facility.

Reliability is rated as the second most important factor. It typically implies the stability of performance, the ability to work properly under most environmental and weather conditions, and the capability to resist external disturbances. The accuracy of the devices should not be very sensitive to changing weather conditions. This requirement is especially important in certain areas where a specific weather characteristic occurs frequently, such as snow in Minnesota in winter or rain in Florida in summer.

Durability and functionality are ranked tied as the third important factors. Durability implies a common desire that the devices work correctly for long time periods, thereby precluding frequent purchase/installation costs, and calibration efforts. 
Table 3.3 Ranking of Factors based on the Survey

\begin{tabular}{|c|c|c|c|c|c|c|c|c|c|c|c|c|}
\hline User ID & $\begin{array}{l}\text { Work } \\
\text { Type } \\
\end{array}$ & Experience & Price & Accuracy & Durability & Reliability & Portability & \begin{tabular}{|c|} 
Data \\
Retrieval \\
\end{tabular} & Installation & Functionality & Training & Maintenance \\
\hline 1 & 1 & 2 & 7 & 1 & 3 & 2 & 4 & 6 & 9 & 5 & 10 & 8 \\
\hline 2 & 1 & & 3 & 1 & 8 & 2 & 10 & 5 & 7 & 4 & 6 & 9 \\
\hline 3 & 1 & 10 & 5 & 3 & 2 & 1 & 4 & 6 & 7 & 8 & 9 & 10 \\
\hline 4 & 1 & 8 & 6 & 1 & 3 & 2 & 8 & 4 & 7 & 5 & 9 & 6 \\
\hline 5 & 1 & 20 & 5 & 1 & 4 & 3 & 10 & 6 & 7 & 8 & 9 & 2 \\
\hline 6 & 3 & 9 & 5 & 1 & 2 & 1 & 9 & 8 & 5 & 2 & 5 & 2 \\
\hline 7 & 1 & 9 & 8 & 2 & 3 & 1 & 5 & 7 & 4 & 6 & 10 & 9 \\
\hline 8 & 1 & 4 & 7 & 6 & 8 & 4 & 9 & 3 & 2 & 1 & 5 & 10 \\
\hline 9 & 1 & 20 & 6 & 1 & 3 & 2 & 10 & 5 & 8 & 4 & 9 & 7 \\
\hline 10 & 1 & 3 & 9 & 1 & 6 & 2 & 7 & 5 & 3 & 4 & 8 & 10 \\
\hline 11 & 2 & 15 & 10 & 1 & 2 & 2 & 6 & 4 & 9 & 5 & 7 & 8 \\
\hline 12 & 1 & 10 & 4 & 1 & 7 & 2 & 6 & 5 & 3 & 8 & 10 & 9 \\
\hline 13 & 1 & 10 & 3 & 1 & 2 & 1 & 2 & 4 & 3 & 4 & 3 & 7 \\
\hline 14 & 1 & 7 & 9 & 1 & 3 & 2 & 8 & 6 & 5 & 4 & 10 & 7 \\
\hline 15 & 1 & 10 & 3 & 1 & 2 & 1 & 5 & 3 & 1 & 2 & 5 & 3 \\
\hline 16 & 1 & 8 & 6 & 5 & 3 & 1 & 5 & 1 & 2 & 3 & 3 & 6 \\
\hline 17 & 4 & 15 & 10 & 1 & 8 & 2 & 5 & 6 & 4 & 3 & 7 & 9 \\
\hline 18 & 1 & 4 & 3 & 1 & 2 & 4 & 6 & 5 & 7 & 8 & 10 & 9 \\
\hline 19 & 1 & 2 & 3 & 2 & 5 & 1 & 10 & 4 & 6 & 7 & 9 & 8 \\
\hline 20 & 1 & 2 & 8 & 3 & 4 & 1 & 6 & 5 & 2 & 7 & 10 & 9 \\
\hline Average & & 8.84 & 6.00 & 1.75 & 4.00 & 1.85 & 6.75 & 4.90 & 5.05 & 4.90 & 7.70 & 7.40 \\
\hline Rank & & & 7 & 1 & 3 & 2 & 8 & 5 & 6 & 4 & 10 & 9 \\
\hline
\end{tabular}




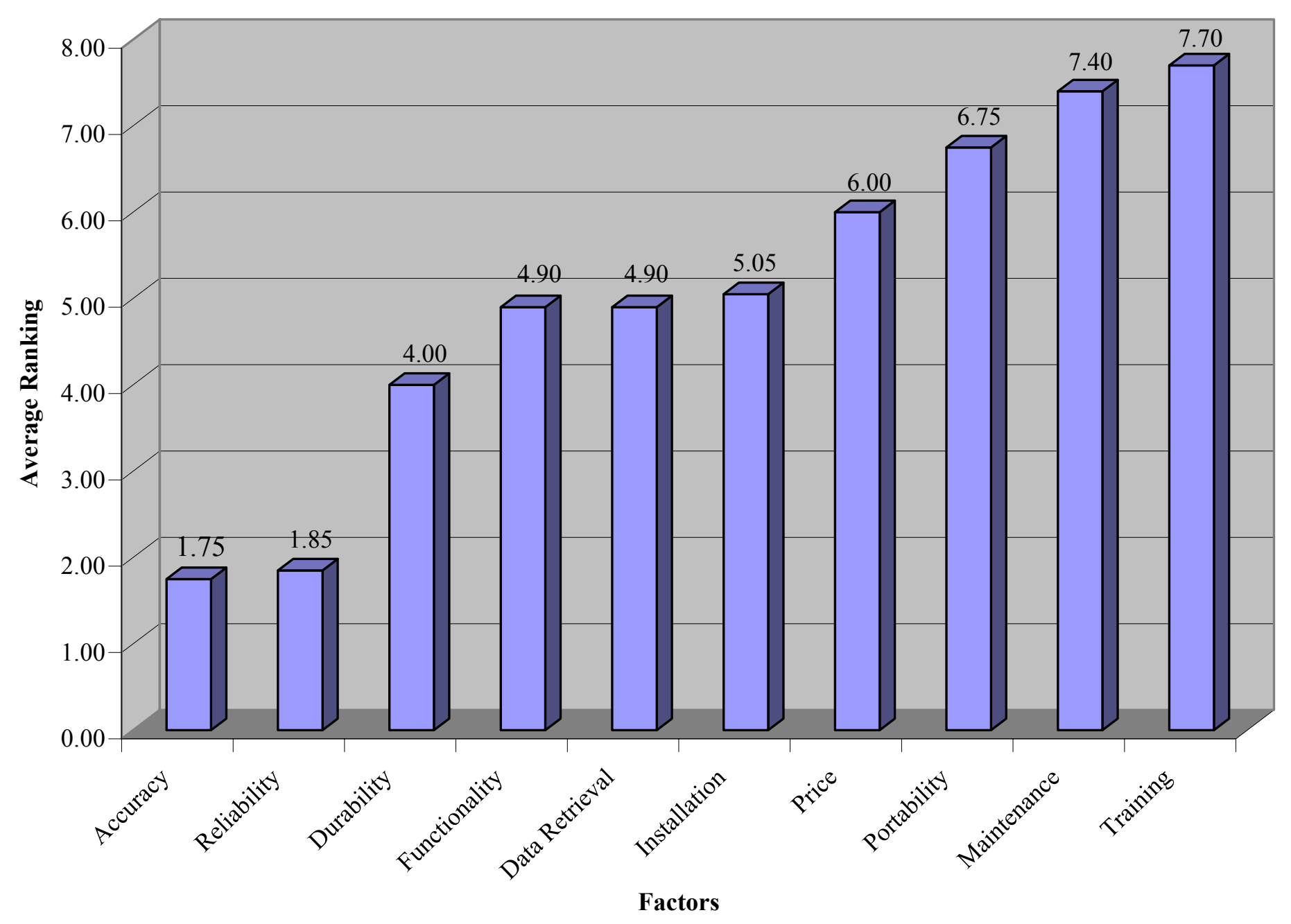

Figure 3.2 Ranking of Selection Factors 
Functionality reflects the need for more comprehensive traffic-related data under ITS for transportation system operations. While most traditional counting devices can measure speed, volume, density, and occupancy, recent applications entail the need for vehicle classification, vehicle identification, queue detection, and weather/environment information. Thus, the versatility of the device is an important factor.

Ease of data retrieval and ease of installation are the next two important factors. A traffic counting device with efficient and user-friendly software interface to manipulate the collected data is desired. The ease of installation focuses primarily on the range of locations that a device can be mounted at, the effort needed for installation, the disturbance to the ambient traffic during installation, the damage to the roadway surface, and the safety of installation personnel.

Surprisingly, the equipment price was not significantly emphasized by the users. This implies the willingness to pay more for accurate, reliable, and versatile counting devices. Portability, maintenance needs, and personnel training needs are rated among the least important factors. This suggests that traffic agencies are willing to invest more in maintenance and training efforts if accurate and reliable data can be ensured.

The survey rating of factors is subjective, and is based on the generic need for traffic counting devices. However, some users may have specific data needs or objectives and/or specific environmental conditions. Hence, such users may rank the various factors differently.

The third question set in the survey was aimed at eliciting the traffic data needs of the users. Traffic volumes, speed, classification, vehicle counts, gap, and turning movement counts are the most commonly mentioned needs. Most respondents indicate 
that their current counting devices address the basic data needs. However, some mention the need for more accurate, economical or advanced traffic counting devices with the progress of technology.

\subsubsection{Product Evaluation}

An important step in the two-step selection procedure is to rate each device on each factor. This step is difficult because: (i) factor characteristics; it is difficult to obtain quantitative values for some factors, (ii) incomplete specification; vendors may not provide all the required data, and (iii) subjectivity; the performance of a product may vary across users due to the specific field conditions in each situation.

In the user survey, the fourth set of questions asked respondents to evaluate the traffic counting devices being used in their state/district. The performance of each model is evaluated by rating some major factors. 45 evaluations were received for 20 products. The survey shows that inductive loops are the primary detector devices currently.

The product evaluation results are listed in Appendix D. They indicate that even for the same products, different users may have very different evaluations. It should be noted that the product evaluation results represent only the opinions of the individuals who answered the survey questions based on their experience with traffic counting devices at particular locations. Hence, the results are subjective. Also, the performance of a single unit of a device under specific circumstances may not necessarily represent the typical performance of that technology or model under other circumstances. Hence, the evaluation results are not comprehensive and can only be used as a reference to select counting devices. This emphasizes the sparseness in studies related to the evaluation of 
traffic counting devices. It also indicates the need for a nation-wide study and a standard evaluation system to provide guidance for the selection of traffic counting devices. 


\section{CHAPTER 4 TRAFFIC COUNTING DEVICE DATABASES}

Based on a thorough search of available traffic counting devices, traffic counting device databases were built using Microsoft Access. Some basic aspects of Microsoft Access vis-à-vis this study are introduced in Appendix E. Currently 99 products from 32 vendors are recorded in the database. The information for the database was obtained from: (i) the Internet, (ii) existing reports, surveys and databases, and (iii) vendor product brochures.

\subsection{Descriptions of the Traffic Counting Device Databases}

The traffic counting device databases provided along this report were created using Microsoft Access (2000 version) which is part of the Microsoft Office 2000 Professional suit. The databases can also be accessed through Access XP or converted into Access 97 format. There are 4 major components in the database file: Product, Vendor, Software, and Product Evaluation tables.

\subsubsection{Product Table}

The product database contains detailed data on the traffic counting devices. Currently, this table has 99 products. The fields in this table are classified into four groups:

\section{Group 1: Basic Information}

1) Product ID (primary key)

2) Vendor ID (the ID number of the vendor that produces this product)

3) Model Name (the model name specified by the vendor)

4) Detector Type (1-infrared, 2-magnetic, 3-microwave, 4-passive acoustic, 5ultrasonic, 6-video, 7-inductive loop, 8-other, specify)

5) Price (unit price, in U.S. Dollar); Price Basis (per lane and/or installation fee) 


\section{Group 2: Functions and Applications}

6) Traffic Data (the traffic data types that the detector can collect. May includes vehicle counting, density, speed, volume, occupancy, headway, queue length, pedestrian presence, etc.)

7) Vehicle Information (registration plate number identification, vehicle classification and/or class counting, vehicle passenger occupancy, or vehicle conditions)

8) Weather Data (Y if weather-related data can be recorded; otherwise N)

9) Roadway Condition ( $Y$ if roadway pavement conditions can be measured; otherwise N)

10) Incident Detection ( $Y$ if incident can be detected or recreated; otherwise $N$ )

11) Other Data

\section{Group 3: Features}

12) Installation Position (1-overhead, 2-roadside, 3-underground, 4-mobile, 5-other)

13) Ease of Installation ( $\mathrm{Y} / \mathrm{N} ; \mathrm{Y}$ if it is easy to install)

14) Ease of Operation ( $\mathrm{Y} / \mathrm{N}$; Y if simple to operate)

15) Coverage (number of lanes that can be covered)

16) Count per Second (maximum number of vehicles that can be counted in one second)

17) Detecting Speed (speed range that can be captured; in miles/hour)

18) Working Temperature (temperature range in which the detector can work properly; in ${ }^{\circ} \mathrm{C}$ )

19) Humidity Range (humidity range the detector can work properly; in percentage) 
20) Auxiliary Devices (special devices or communication connection needed)

21) Software Support (description of software functions and output if support software is available)

22) Personnel Training ( $\mathrm{Y}$ if special personnel training is needed; otherwise $\mathrm{N}$ )

23) Maintenance Needs ( $Y$ if regular maintenance needed; otherwise $N$ )

24) Other Main Features (may include special installation requirements, waterproofing, flexibility in customization and optimization, mobility, etc.)

\section{Group 4: Main Parameters}

25) Life Span (duration of service; in years)

26) Year First Produced (the year the product was first produced)

27) Size (maximum outer box size; length $\times$ width $\times$ height, in $\mathrm{ft}^{3}$ )

28) Power Supply (battery life span or electrical power consumed)

29) Other Parameters

30) Other Remarks

\subsubsection{Vendor Table}

The vendor database provides information about the vendors. It contains 32 records with six fields. The fields include:

1) Vendor ID (primary key)

2) Company Name (the full name of the vendor)

3) Address

4) Phone (10-digit phone number)

5) E-mail address

6) URL (address) 
There is a relationship between the Vendor Database and the Product Database. The vendor ID of a certain device in the Product Database is the primary key of this vendor in the Vendor Database.

\subsubsection{Software Table}

Some vendors provide software packages along with traffic counting devices to retrieve, process, analyze or store traffic data. This database contains the following 5 fields:

1) Software ID (primary Key)

2) Vendor ID (the ID of vendor who provides this software)

3) Name (the software name)

4) Capabilities (the functions of this software)

5) Output (the output data of this software)

Currently, there are 14 software records in this database. The Software Database is related to the Vendor Database through the Vendor ID.

\subsubsection{Product Evaluation Table}

The Product Evaluation table contains data on user feedback on some products from the survey responses.

\subsection{Custom Queries and Relationships for Traffic Counting Device Databases}

Users can create custom queries according to their specific requirements on some attributes of the counting devices. For example, they can query for devices with particular price range, or the traffic data type needed. In this study, we provide some built-in queries based on the device technology category. The products satisfying these queries are listed in different query tables. In order to open a built-in query, user can click "Queries" entry in the main database window, and open corresponding query tables. A 
view of built-in query is shown in Figure 4.1. Products in each technology category were filtered into different query sheets. A user needs to just click on a particular technology query sheet to see all the products in this technology category. User-specified queries can be built by clicking "Create query in design view" in the database window under "Queries" mode. Microsoft Access will allow users to select data table(s) on which the query is built, and then select the attribute whose value is used as criteria to make the query. Query can also be made based on multiple attributes. New query on existing queries is also available, which makes multi-step filtering possible. To make a multi-step query, user just needs to select existing query table instead of data table when building the new query.

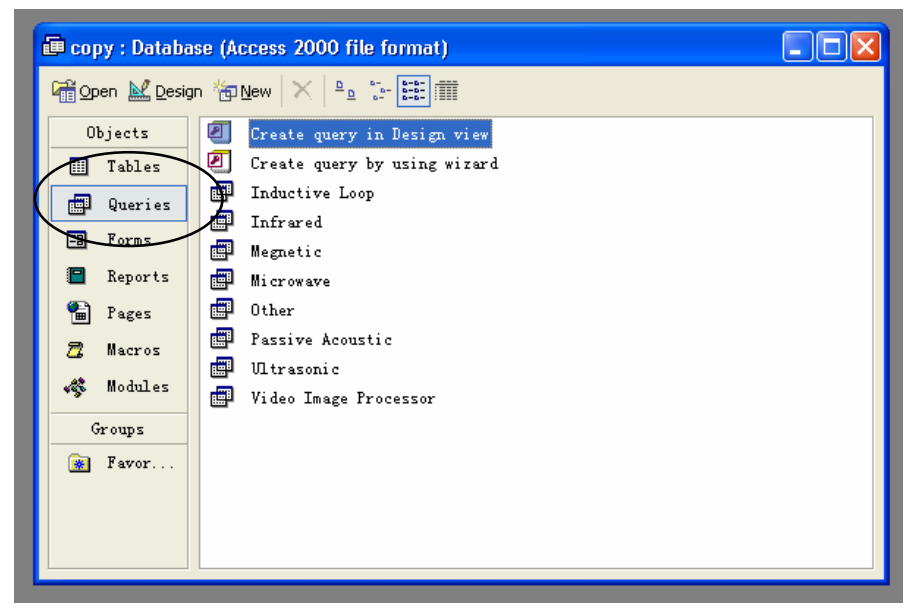

Figure 4.1 Example of Built-in Queries

Tables in the same database file may be connected through some common fields. This is called the relationship between the tables. The relationships among the main tables in the traffic counting device databases are shown in Figure 4.2. The Product table and the Vendor table are connected through the field "Vendor ID". Similarly, the Product 
table is connected to the Product Evaluation table through "Product ID", and the Vendor table is connected to the Software table through "Vendor ID".

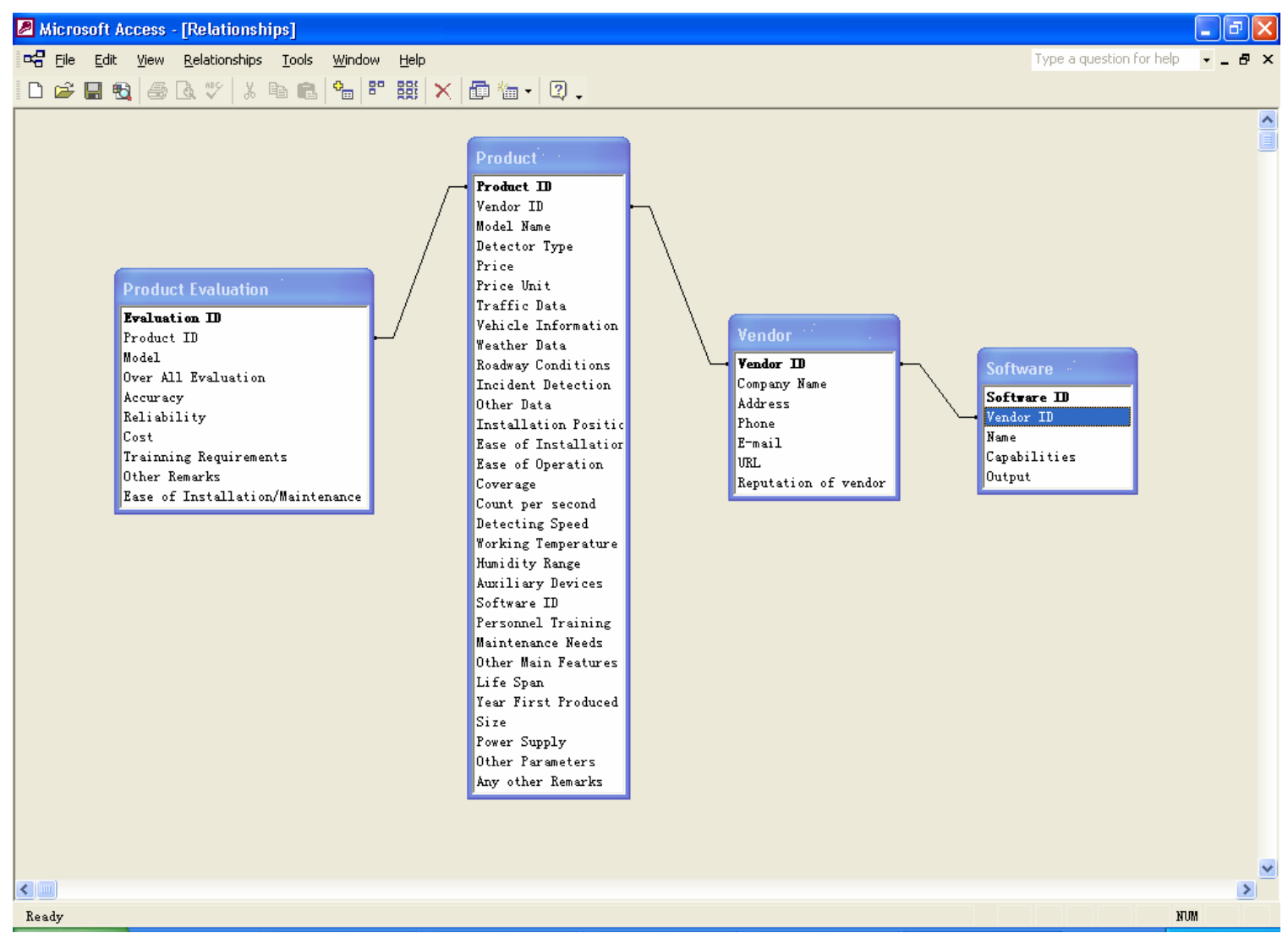

Figure 4.2 Relationships in Product Databases

\subsection{Further Improvement to the Traffic Counting Device Databases}

The traffic counting device databases contain a comprehensive listing of the devices that are currently available in the market. However, currently, some products have incomplete information due to the limited information provided by the vendors. Hence, some attributes of some products are not specified. Second, the various attributes may not have a consistent basis across vendors because different vendors specify different aspects of an attribute. For example, some vendors provide the price of one unit of a device, while 
others show the cost per lane and view costs in terms of lane coverage. Other vendors provide the price of an integrated system including probes, data processing equipment, and sometimes even installation cost. This makes comparison difficult unless the various aspects can be separated. Third, some attributes lack numerical values and can only be evaluated through description. Users need to convert them into comparable values before being able to rate the products. Despite these problems, to our knowledge, the database is the most complete one in literature in terms of the number of products recorded and the amount of information collected. It can be used as an auxiliary tool to select traffic counting devices. 


\section{CHAPTER 5 CONCLUSIONS}

Accurate traffic data detection is essential for the successful implementation of ITS. The collection of real-time traffic data is an integral part of ATIS and ATMS, and is necessary for the validation of these technologies. In addition, the collection and processing of historical traffic data is essential for transportation system planning and operation.

Currently, inductive loop detectors are the most commonly used traffic counting devices in the field. Being a mature technology, the traditional intrusive device has many advantages such as low cost, high accuracy and stable performance. However, there are some important drawbacks of using intrusive devices. They include the labor-intensive nature of installation, interruption of traffic, damage to road surface, geographical restrictions, and limited data type. New technologies are being developed to meet growing data counting and traffic surveillance needs. They include passive infrared, active infrared, passive magnetic, Doppler microwave, radar, passive acoustic, pulse and Doppler ultrasonic, and video image. Each has its advantages and disadvantages, and is suitable under some circumstances or for certain data collection needs. However, due to the lack of widespread development of these technologies, their relative novelty, rapid proliferation, and lack of homogeneity in standards, systematic selection guidelines are unavailable for these devices.

There are some studies in the literature that collect information on available detectors and/or evaluate their performance through field tests. However, no study specifically addresses detector selection criteria and selection process. 
This study first identifies the factors that influence the selection of traffic counting devices. Device-related factors include accuracy and reliability, cost, ease of installation and maintenance, portability and storage, data retrieval, data type and functional capabilities, amenability to future technological advances, and personnel training needs. Besides these factors, the performance of traffic counting devices is also influenced by some environment-related factors such as weather conditions, traffic characteristics, roadway type, installation location and position, and traffic direction. To generate a practical selection procedure, a user survey was conducted among district and/or regional subdivisions of the departments of transportation of six states including California, Florida, Indiana, Minnesota, New York, and Texas. The survey was designed to collect the opinions and experience of these agencies on the relative importance of various factors. In addition, the survey sought feedback on the performance of traffic counting devices currently being used by these agencies. The various factors listed in the descending order of importance based on the survey are: accuracy, reliability, durability, functionality, data retrieval, ease of installation, price, portability, maintenance needs, and personnel training needs.

A selection procedure was proposed based on the survey results. An important step in the selection procedure is the comprehensive understanding of the various technologies and products currently available in the market. To accomplish this objective, a set of traffic counting device databases was built using Microsoft Access. Currently 99 products from 32 vendors are recorded in the databases. Detailed information on each device model is recorded and classified using the various attributes. The databases 
represent a comprehensive collection of traffic counting devices that are currently available in the market.

The study concludes that there are still some barriers to the systematic evaluation and informed selection of traffic counting devices. They include lack of universal standards, incomplete specification of product parameters, inconsistent bases to describe attributes among vendors, and the difficulty in obtaining quantitative values for some important attributes. These issues preclude a consistent comparison between the candidate products. They indicate the need for a nation-wide comprehensive study of traffic counting devices that involves setting homogenous standards, developing consistency in the description of product parameters, and systematic tests of the various products under different environmental and traffic conditions. 
Appendix A: Product Information by Technology Category 


\begin{tabular}{|c|c|c|c|c|c|c|c|c|c|c|}
\hline \multicolumn{11}{|c|}{ Infrared } \\
\hline \begin{tabular}{|c|}
$\begin{array}{c}\text { Product } \\
\text { ID }\end{array}$ \\
\end{tabular} & Company Name & Model Name & \begin{tabular}{|c|}
$\begin{array}{c}\text { Detector } \\
\text { Type }\end{array}$ \\
\end{tabular} & Price & $\begin{array}{l}\text { Price } \\
\text { Unit } \\
\end{array}$ & Traffic Data & \begin{tabular}{|c|}
$\begin{array}{c}\text { Installation } \\
\text { Position }\end{array}$ \\
\end{tabular} & Coverage & 0ther Main Features & Any other Remarks \\
\hline 1002 & $\begin{array}{l}\text { ASIM } \\
\text { Technologies } \\
\text { Ltd }\end{array}$ & $\begin{array}{l}\text { IR } 250 \text { Series } \\
\text { Multichannel } \\
\text { PIR Vehicle } \\
\text { Detector }\end{array}$ & 1 & 737 & & $\begin{array}{l}\text { presence, } \\
\text { count, speed }\end{array}$ & 1,2 & 1 lane & $\begin{array}{l}\text { mounting height from } 4 \\
\text { to } 10 \text { meters, static } \\
\text { and dynamic sensors, } \\
\text { IP } 64 \text { splash proof }\end{array}$ & $\begin{array}{l}\text { temperature contrast } \\
\text { compensation, }\end{array}$ \\
\hline 1003 & $\begin{array}{l}\text { ASIM } \\
\text { Technologies } \\
\text { Ltd }\end{array}$ & $\begin{array}{l}\text { DT } 270 \text { Series } \\
\text { Dual technology } \\
\text { PIR and US } \\
\text { detectors }\end{array}$ & 1,5 & 681 & & $\begin{array}{l}\text { presence \& } \\
\text { queue } \\
\text { detection, } \\
\text { count, }\end{array}$ & 1,2 & 1 lane & $\begin{array}{l}\text { horizontal or vertical } \\
\text { mounting, IP } 64 \text { splash } \\
\text { proof, static presence } \\
\text { and distance dependant } \\
\text { detection }\end{array}$ & easy mounting \\
\hline 1004 & $\begin{array}{l}\text { ASIM } \\
\text { Technologies } \\
\text { Ltd }\end{array}$ & $\begin{array}{l}\text { TT } 260 \text { Series } \\
\text { Triple } \\
\text { technology PIR } \\
\text { / US / MW } \\
\text { detectors }\end{array}$ & $1,3,5$ & 1786 & & $\begin{array}{l}\text { Count, speed, } \\
\text { presence \& } \\
\text { queue } \\
\text { detection, } \\
\text { occupancy \& } \\
\text { time gap } \\
\text { detection }\end{array}$ & 1 & 1 lane & $\begin{array}{l}\text { IP } 64 \text { splash proof, } \\
\text { mounting height, } \\
\text { detection of ghost } \\
\text { riders, detection of } \\
\text { alternating traffic, } \\
\text { self calibrating }\end{array}$ & Easy installation \\
\hline 1014 & $\begin{array}{l}\text { Diamond } \\
\text { Traffic } \\
\text { Products }\end{array}$ & TT-3 & $\begin{array}{l}1,8^{-} \\
\text {seismic }\end{array}$ & 210 & & count & $\begin{array}{l}4 \text { (on } \\
\text { pavement) }\end{array}$ & 1 lane & $\begin{array}{l}\text { waterproof, magnetic } \\
\text { zero reset, aluminum } \\
\text { case with lock and } \\
\text { cover, }\end{array}$ & $\begin{array}{l}6 \text { digit liquid crystal } \\
\text { display, best suited } \\
\text { for counting low } \\
\text { volumes. ease of } \\
\text { installation }\end{array}$ \\
\hline 1085 & $\begin{array}{l}\text { Scientific } \\
\text { Technologies, } \\
\text { Inc. }\end{array}$ & $\begin{array}{l}\text { VS6500 Vehicle } \\
\text { Scanner }\end{array}$ & 1 & & & & 2 & 1 lane & $\begin{array}{l}\text { specifically designed } \\
\text { for vehicle detection } \\
\text { and classification in } \\
\text { automated toll } \\
\text { systems, Fan prevents } \\
\text { overheating in summer }\end{array}$ & $\begin{array}{l}\text { rugged stainless steel } \\
\text { design or aluminum with } \\
\text { corrosion resistant } \\
\text { paint, Three separate } \\
\text { outputs: RS-232 or RS- } \\
422 \text { serial data, } \\
\text { parallel data, and } \\
\text { relay }\end{array}$ \\
\hline
\end{tabular}




\begin{tabular}{|c|c|c|c|c|c|c|c|c|c|c|}
\hline \multicolumn{11}{|c|}{ Magnetic } \\
\hline \begin{tabular}{|c|} 
Product \\
ID \\
\end{tabular} & Company Name & Model Name & \begin{tabular}{|c|}
$\begin{array}{c}\text { Detector } \\
\text { Type }\end{array}$ \\
\end{tabular} & Price & Price Unit & Traffic Data & \begin{tabular}{|c|}
$\begin{array}{c}\text { Installation } \\
\text { Position }\end{array}$ \\
\end{tabular} & Coverage & $\begin{array}{c}\text { Other Main } \\
\text { Features }\end{array}$ & Any other Remarks \\
\hline 1000 & $\begin{array}{l}\text { 3M, Intelligent } \\
\text { Transportation } \\
\text { Systems }\end{array}$ & \begin{tabular}{|l}
$3 \mathrm{M}^{\mathrm{TM}}$ \\
Traffic \\
Sensing \\
System \\
(Mode1 \\
$701)$
\end{tabular} & 2 & & & $\begin{array}{l}\text { speed, } \\
\text { counting, } \\
\text { ramp } \\
\text { metering } \\
\text { passage } \\
\text { detection }\end{array}$ & 3 & & $\begin{array}{l}\text { invasive, count } \\
\text { performance } \\
\text { regardless of } \\
\text { weather }\end{array}$ & $\begin{array}{l}0.25^{\prime \prime} \text { saw cuts need to } \\
\text { be made and a } 1^{\prime \prime} \\
\text { diameter hole @ } 20^{\prime \prime} \\
\text { deep, protected from } \\
\text { severe traffic and } \\
\text { environment }\end{array}$ \\
\hline 1001 & $\begin{array}{l}\text { 3M, Intelligent } \\
\text { Transportation } \\
\text { Systems }\end{array}$ & \begin{tabular}{|l}
$3 \mathrm{M}^{\mathrm{TM}}$ \\
Traffic \\
Sensing \\
System \\
(Model \\
$702)$
\end{tabular} & 2 & & & $\begin{array}{l}\text { vehicle } \\
\text { presence, } \\
\text { count, } \\
\text { speed, } \\
\text { length, } \\
\text { roadway } \\
\text { occupancy }\end{array}$ & 3 & & $\begin{array}{l}\text { non-invasive micro } \\
\text { loop, minimal } \\
\text { interruption of } \\
\text { traffic, } \\
\text { maintenance can be } \\
\text { performed on the } \\
\text { side of the road }\end{array}$ & $\begin{array}{l}\text { protected from severe } \\
\text { traffic and } \\
\text { environment, readily } \\
\text { removed, replaced, or } \\
\text { repositioned, } \\
\text { efficient remote } \\
\text { diagnostics, installed } \\
\text { using horizontal } \\
\text { drilling, vdc- } 93\end{array}$ \\
\hline 1041 & $\begin{array}{l}\text { Midian } \\
\text { Electronics, } \\
\text { Inc. }\end{array}$ & $\begin{array}{l}\text { Self- } \\
\text { Powered } \\
\text { Vehicle } \\
\text { Detector }\end{array}$ & 2 & 600 & per lane & $\begin{array}{l}\text { count, } \\
\text { presence }\end{array}$ & 3 & 1 lane & $\begin{array}{l}\text { temperature stable } \\
\text { and self- } \\
\text { calibrating }\end{array}$ & $\begin{array}{l}\text { requires a } 6 " \text { diameter } \\
\text { hole to be drilled in } \\
\text { the traffic lane to a } \\
\text { depth of } 14 \text { inches } \\
\text { below the asphalt, } \\
\text { used in WA, FL, CN. } \\
\text { vdc-95 }\end{array}$ \\
\hline 1056 & $\begin{array}{l}\mathrm{Nu} \text {-Metrics, Inc } \\
\text { - A Quixote } \\
\text { Company }\end{array}$ & $\begin{array}{l}\text { HI-STAR } \\
(\mathrm{NC}-47 \& \\
\text { NC-97) }\end{array}$ & 2 & 975 & per lane & $\begin{array}{l}\text { volume, } \\
\text { speed, } \\
\text { presence }\end{array}$ & 4 & 1 lane & $\begin{array}{l}\text { no tubes, locks or } \\
\text { chains, simple } \\
\text { programming, } \\
\text { collect data at } \\
\text { any location }\end{array}$ & $\begin{array}{l}\text { Vehicle Magnetic } \\
\text { Imaging (VMI) } \\
\text { technology, } 15 \text { speed } \\
\text { categories, } 8 \text { length } \\
\text { categories, Real-Time- } \\
\text { Clock, used: PA, NC, } \\
\text { M0, IL, FL, TX, AL, } \\
\text { CA, CO, AZ, NV, LA }\end{array}$ \\
\hline
\end{tabular}




\begin{tabular}{|c|c|c|c|c|c|c|c|c|c|c|}
\hline \multicolumn{11}{|c|}{ Magnetic } \\
\hline \begin{tabular}{|c|} 
Product \\
ID
\end{tabular} & Company Name & Model Name & $\begin{array}{c}\text { Detector } \\
\text { Type }\end{array}$ & Price & Price Unit & Traffic Data & $\begin{array}{c}\text { Installation } \\
\text { Position }\end{array}$ & Coverage & $\begin{array}{c}\text { Other Main } \\
\text { Features }\end{array}$ & Any other Remarks \\
\hline 1057 & $\begin{array}{l}\mathrm{Nu} \text {-Metrics, Inc } \\
\text { - A Quixote } \\
\text { Company }\end{array}$ & $\begin{array}{l}\text { COUNTCARD } \\
\text { NC-30X }\end{array}$ & 2 & 275 & per lane & volume & 4 & - & $\begin{array}{l}\text { simple two button } \\
\text { operation, } \\
\text { programmable start } \\
\text { count hour, auto } \\
\text { stop at } 1,6,12 \\
\text { hours, } 1 \text { to } 7 \text { days }\end{array}$ & $\begin{array}{l}\text { operated by two keys } \\
\text { and a } 6 \text {-digit display, } \\
\text { real time quartz } \\
\text { clocks, maximum count } \\
999,999 \text { vehicles }\end{array}$ \\
\hline 1058 & $\begin{array}{l}\mathrm{Nu} \text {-Metrics, Inc } \\
\text { - A Quixote } \\
\text { Company }\end{array}$ & $\begin{array}{l}\text { GROUNDHOG } \\
\text { G1 }\end{array}$ & 2 & 975 & $\begin{array}{l}\text { per lane. } \\
\text { installation: } \\
150\end{array}$ & $\begin{array}{l}\text { volume } \\
\text { counts, gap }\end{array}$ & 3 & 1 lane & $\begin{array}{l}\text { license free } \\
\text { spread spectrum } \\
\text { RF, no loops, } \\
\text { tubes or chains, } \\
\text { time period data } \\
\text { (1-120 minutes), } \\
\text { used: Penn D0T }\end{array}$ & $\begin{array}{l}\text { vehicle detection and } \\
\text { measurement are } \\
\text { accomplished by } \\
\text { Vehicle Magnetic } \\
\text { Imaging (VMI }{ }^{\mathrm{TM}} \text { ) } \\
\text { Technology, stores } \\
\text { accurate and essential } \\
\text { real-time traffic data }\end{array}$ \\
\hline 1059 & $\begin{array}{l}\mathrm{Nu} \text {-Metrics, Inc } \\
\text { - A Quixote } \\
\text { Company }\end{array}$ & $\begin{array}{l}\text { GROUNDHOG } \\
\text { G2 }\end{array}$ & 2 & 1695 & $\begin{array}{l}\text { per lane. } \\
\text { installation: } \\
150\end{array}$ & $\begin{array}{l}\text { volume } \\
\text { counts, } \\
\text { speed, gap }\end{array}$ & 3 & 1 lane & $\begin{array}{l}\text { license free } \\
\text { spread spectrum } \\
\text { RF, no loops, } \\
\text { tubes or chains, } \\
\text { time period data } \\
\text { (1-120 minutes), } \\
\text { used Penn D0T }\end{array}$ & $\begin{array}{l}\text { vehicle detection and } \\
\text { measurement are } \\
\text { accomplished by } \\
\text { Vehicle Magnetic } \\
\text { Imaging (VMI }{ }^{\mathrm{TM}} \text { ) } \\
\text { Technology }\end{array}$ \\
\hline 1060 & $\begin{array}{l}\text { Nu-Metrics, Inc } \\
\text { - A Quixote } \\
\text { Company }\end{array}$ & $\begin{array}{l}\text { GROUNDHOG } \\
\text { G2WX }\end{array}$ & 2 & 1800 & per lane & $\begin{array}{l}\text { volume } \\
\text { counts, } \\
\text { speed }\end{array}$ & 3 & $\begin{array}{l}1-64 \\
\text { (BSR/RFM- } \\
915 \\
\text { required) }\end{array}$ & $\begin{array}{l}\text { license free } \\
\text { spread spectrum } \\
\text { RF, no loops, } \\
\text { tubes or chains, } \\
\text { time period data } \\
\text { (1-120 minutes), }\end{array}$ & $\begin{array}{l}\text { vehicle detection and } \\
\text { measurement are } \\
\text { accomplished by } \\
\text { Vehicle Magnetic } \\
\text { Imaging (VMI }{ }^{\mathrm{TM}} \text { ) } \\
\text { Technology, stores } \\
\text { accurate and essential } \\
\text { real-time traffic } \\
\text { conditions }\end{array}$ \\
\hline 1061 & $\mathrm{Nu}$-Metrics, Inc & GROUNDHOG & 2 & & & volume & 3 & - & license free & vehicle detection and \\
\hline
\end{tabular}




\begin{tabular}{|c|c|c|c|c|c|c|c|c|c|c|}
\hline \multicolumn{11}{|c|}{ Magnetic } \\
\hline \begin{tabular}{|c|} 
Product \\
ID
\end{tabular} & Company Name & Model Name & $\begin{array}{c}\text { Detector } \\
\text { Type }\end{array}$ & Price & Price Unit & Traffic Data & \begin{tabular}{|c|} 
Installation \\
Position
\end{tabular} & Coverage & $\begin{array}{c}\text { Other Main } \\
\text { Features }\end{array}$ & Any other Remarks \\
\hline & $\begin{array}{l}\text { - A Quixote } \\
\text { Company }\end{array}$ & G3 & & & & counts & & & $\begin{array}{l}\text { spread spectrum } \\
\text { RF, no loops, } \\
\text { tubes or chains, } \\
\text { time period data } \\
\text { (1-120 minutes), }\end{array}$ & $\begin{array}{l}\text { measurement are } \\
\text { accomplished by } \\
\text { Vehicle Magnetic } \\
\text { Imaging (VMI }) \\
\text { Technology, stores } \\
\text { accurate and essential } \\
\text { real-time traffic } \\
\text { conditions }\end{array}$ \\
\hline 1062 & $\begin{array}{l}\mathrm{Nu} \text {-Metrics, Inc } \\
\text { - A Quixote } \\
\text { Company }\end{array}$ & $\begin{array}{l}\text { GROUNDHOG } \\
\text { G3WX }\end{array}$ & 2 & & & $\begin{array}{l}\text { volume } \\
\text { counts }\end{array}$ & 3 & - & $\begin{array}{l}\text { license free } \\
\text { spread spectrum } \\
\text { RF, no loops, } \\
\text { tubes or chains, } \\
\text { time period data } \\
\text { (1-120 minutes), }\end{array}$ & $\begin{array}{l}\text { vehicle detection and } \\
\text { measurement are } \\
\text { accomplished by } \\
\text { Vehicle Magnetic } \\
\text { Imaging (VMI }{ }^{\mathrm{TM}} \text { ) } \\
\text { Technology, stores } \\
\text { accurate and essential } \\
\text { real-time traffic } \\
\text { conditions }\end{array}$ \\
\hline
\end{tabular}




\begin{tabular}{|c|c|c|c|c|c|c|c|c|c|c|}
\hline \multicolumn{11}{|c|}{ Microwave } \\
\hline \begin{tabular}{|c|} 
Product \\
ID \\
\end{tabular} & $\begin{array}{c}\text { Company } \\
\text { Name }\end{array}$ & Model Name & $\begin{array}{c}\text { Detector } \\
\text { Type }\end{array}$ & $\begin{array}{c}\text { Price } \\
(\$)\end{array}$ & Price basis & $\begin{array}{c}\text { Traffic } \\
\text { Data } \\
\end{array}$ & \begin{tabular}{|c}
$\begin{array}{c}\text { Installation } \\
\text { Position }\end{array}$ \\
\end{tabular} & Coverage & 0ther Main Features & Any other Remarks \\
\hline 1026 & \begin{tabular}{|l|} 
EIS, \\
Electronic \\
Integrated \\
Systems Inc.
\end{tabular} & RTMS/FTMS & 3 & & & $\begin{array}{l}\text { volume, } \\
\text { speed, gap }\end{array}$ & 2 & 8 lanes & $\begin{array}{l}\text { accurate in all } \\
\text { weather conditions, } \\
\text { low cost, mounting: } \\
\text { Side-fired or } \\
\text { Forward-looking }\end{array}$ & $\begin{array}{l}\text { output information is } \\
\text { provided to existing } \\
\text { controllers via contact } \\
\text { pairs and to computer } \\
\text { systems via a RS-232 } \\
\text { serial communications port }\end{array}$ \\
\hline 1027 & \begin{tabular}{|l|} 
EIS, \\
Electronic \\
Integrated \\
Systems Inc.
\end{tabular} & RTMS-WATER & 3 & & & $\begin{array}{l}\text { count, } \\
\text { occupancy, } \\
\text { speed, } \\
\text { presence }\end{array}$ & 2 & 8 lanes & $\begin{array}{l}\text { accurate measurement } \\
\text { in all weather } \\
\text { conditions, few } \\
\text { leased-lines } \\
\text { required, Flexible: } \\
\text { Scalable system for } \\
\text { easy growth }\end{array}$ & $\begin{array}{l}\text { data in real-time, Cluster } \\
\text { Controllers: concentrate } \\
\text { data from many stations, } \\
\text { Alarm and special } \\
\text { occurrence reporting, vdc- } \\
166\end{array}$ \\
\hline 1028 & \begin{tabular}{|l|} 
EIS, \\
Electronic \\
Integrated \\
Systems Inc.
\end{tabular} & RTCP & 3 & & & $\begin{array}{l}\text { volume, } \\
\text { speed }\end{array}$ & 2 & 8 lanes & $\begin{array}{l}\text { accurate all-weather } \\
\text { operation, no lane } \\
\text { closures during } \\
\text { installation, high } \\
\text { capacity: } 7 \text { days at } \\
\text { 5-minute intervals }\end{array}$ & $\begin{array}{l}\text { solar generator/charger } \\
\text { options, power-fail data } \\
\text { protection, Laptop PC or } \\
\text { modem data retrieval, MS } \\
\text { Access 97-based analysis } \\
\text { and report software }\end{array}$ \\
\hline 1038 & $\begin{array}{l}\text { Microwave } \\
\text { Sensors, Inc }\end{array}$ & $\begin{array}{l}\text { TC-20 } \\
\text { Vehicle } \\
\text { Detector }\end{array}$ & 3 & 629 & $\begin{array}{l}\text { per lane. } \\
\text { Installation } \\
\$ 500\end{array}$ & & $\begin{array}{l}1,2 \\
(\text { portable })\end{array}$ & $\begin{array}{l}\text { up to } 6 \\
\text { lanes }\end{array}$ & $\begin{array}{l}\text { adjustable range, no } \\
\text { seasonal tuning } \\
\text { required, no } \\
\text { external amplifier } \\
\text { required, Doppler }\end{array}$ & $\begin{array}{l}\text { aluminum with stainless } \\
\text { steel case, heavy-duty } \\
\text { bracket (Predrilled \& } \\
\text { slotted for pole mount), } \\
\text { detects smallest licensed } \\
\text { vehicle }\end{array}$ \\
\hline 1039 & $\begin{array}{l}\text { Microwave } \\
\text { Sensors, Inc }\end{array}$ & $\begin{array}{l}\text { TC-26B } \\
\text { Vehicle } \\
\text { Detector }\end{array}$ & 3 & 735 & $\begin{array}{l}\text { per lane } \\
\text { Installation: } \\
\$ 500\end{array}$ & & $\begin{array}{l}1,2 \\
(\text { portable) }\end{array}$ & $\begin{array}{l}\text { up to } 6 \\
\text { lanes }\end{array}$ & $\begin{array}{l}\text { field ad justable } \\
\text { range, directional } \\
\text { scanning, no } \\
\text { seasonal tuning } \\
\text { required, no }\end{array}$ & $\begin{array}{l}\text { aluminum with stainless } \\
\text { steel case, heavy-duty } \\
\text { bracket (Predrilled \& } \\
\text { slotted for pole mount), } \\
\text { detects smallest licensed }\end{array}$ \\
\hline
\end{tabular}




\section{Microwave}

\begin{tabular}{|c|c|c|c|c|c|c|c|c|c|c|}
\hline $\begin{array}{c}\text { Product } \\
\text { ID }\end{array}$ & $\begin{array}{l}\text { Company } \\
\text { Name }\end{array}$ & Model Name & $\begin{array}{c}\text { Detector } \\
\text { Type }\end{array}$ & $\begin{array}{c}\text { Price } \\
(\$)\end{array}$ & Price basis & $\begin{array}{c}\text { Traffic } \\
\text { Data }\end{array}$ & $\begin{array}{c}\text { Installation } \\
\text { Position }\end{array}$ & Coverage & 0ther Main Features & Any other Remarks \\
\hline & & & & & & & & & $\begin{array}{l}\text { external amplifier } \\
\text { required }\end{array}$ & $\begin{array}{l}\text { vehicle, } 5000+\text { installed } \\
\text { in US }\end{array}$ \\
\hline 1040 & $\begin{array}{l}\text { Microwave } \\
\text { Sensors, Inc }\end{array}$ & \begin{tabular}{|l} 
TC $-30 \quad \&$ \\
TC-30C \\
Presence \\
Sensors
\end{tabular} & 3 & 475 & $\begin{array}{l}\text { per lane } \\
\text { installation: : } \\
\$ 500\end{array}$ & counts & $\begin{array}{l}1,2 \\
(\text { portable) }\end{array}$ & 1 lane & $\begin{array}{l}\text { high speed } \\
\text { transducer for } \\
\text { target resolution, } \\
\text { no seasonal tuning } \\
\text { required, no } \\
\text { external amplifier } \\
\text { required }\end{array}$ & $\begin{array}{l}\text { aluminum with stainless } \\
\text { steel case, heavy-duty } \\
\text { bracket (Predrilled \& } \\
\text { slotted for pole mount), } \\
\text { detects smallest licensed } \\
\text { vehicle }\end{array}$ \\
\hline
\end{tabular}




\begin{tabular}{|c|c|c|c|c|c|c|c|c|c|c|}
\hline \multicolumn{11}{|c|}{ Passive Acoustic } \\
\hline \begin{tabular}{|c|} 
Product \\
ID \\
\end{tabular} & $\begin{array}{c}\text { Company } \\
\text { Name }\end{array}$ & $\begin{array}{c}\text { Model } \\
\text { Name } \\
\end{array}$ & \begin{tabular}{|c|}
$\begin{array}{c}\text { Detector } \\
\text { Type }\end{array}$ \\
\end{tabular} & Price & $\begin{array}{l}\text { Price } \\
\text { Unit }\end{array}$ & Traffic Data & \begin{tabular}{|c|}
$\begin{array}{c}\text { Installation } \\
\text { Position }\end{array}$ \\
\end{tabular} & Coverage & Other Main Features & Any other Remarks \\
\hline 1066 & $\begin{array}{l}\text { PAT } \\
\text { America, } \\
\text { Inc. }\end{array}$ & $\begin{array}{l}\text { ACOUSTIC } \\
\text { SENSOR } \\
\text { SAS-1 }\end{array}$ & 4 & & & $\begin{array}{l}\text { volume, lane } \\
\text { occupancy, } \\
\text { average vehicle } \\
\text { speed }\end{array}$ & 2 & 5 lanes & $\begin{array}{l}\text { Built-in upgrade path } \\
\text { for vehicle type } \\
\text { identification, ideal } \\
\text { back-fit for failed } \\
\text { loops }\end{array}$ & $\begin{array}{l}\text { aluminum case, wireless } \\
\text { option eliminates home run } \\
\text { cables, collects real time } \\
\text { data, stores up to } 60 \text { days } \\
\text { of data, item identical to } \\
\text { SmarTek SAS-1 }\end{array}$ \\
\hline 1086 & $\begin{array}{l}\text { SmarTek } \\
\text { Systsms, } \\
\text { Inc. }\end{array}$ & $\begin{array}{l}\text { ACOUSTIC } \\
\text { SENSOR } \\
\text { SAS-1 }\end{array}$ & 4 & 3500 & & $\begin{array}{l}\text { volume by lane, } \\
\text { lane occupancy, } \\
\text { average vehicle } \\
\text { speed, time }\end{array}$ & 2 & 5 lanes & $\begin{array}{l}\text { Built-in upgrade path } \\
\text { for vehicle type } \\
\text { identification, ideal } \\
\text { back-fit for failed } \\
\text { loops }\end{array}$ & $\begin{array}{l}\text { aluminum case, wireless } \\
\text { option eliminates home run } \\
\text { cables, collects real time } \\
\text { data, stores up to } 60 \text { days } \\
\text { of data, item identical to } \\
\text { PAT SAS-1, vdc-204 }\end{array}$ \\
\hline
\end{tabular}




\section{U1trasonic}

\begin{tabular}{|c|c|c|c|c|c|c|c|c|c|c|}
\hline \begin{tabular}{|c|} 
Product \\
ID \\
\end{tabular} & Company Name & Model Name & \begin{tabular}{|c|}
$\begin{array}{c}\text { Detector } \\
\text { Type }\end{array}$ \\
\end{tabular} & Price & \begin{tabular}{|c|} 
Price \\
Unit \\
\end{tabular} & Traffic Data & \begin{tabular}{|c|}
$\begin{array}{c}\text { Installation } \\
\text { Position }\end{array}$ \\
\end{tabular} & Coverage & 0ther Main Features & Any other Remarks \\
\hline 1003 & $\begin{array}{l}\text { ASIM } \\
\text { Technologies } \\
\text { Ltd }\end{array}$ & $\begin{array}{l}\text { DT } 270 \text { Series } \\
\text { Dual technology } \\
\text { PIR and US } \\
\text { detectors }\end{array}$ & 1,5 & 681 & & $\begin{array}{l}\text { presence \& queue } \\
\text { detection, count, }\end{array}$ & 1,2 & 1 lane & $\begin{array}{l}\text { horizontal or vertical } \\
\text { mounting, IP } 64 \text { splash } \\
\text { proof, static presence } \\
\text { and distance dependant } \\
\text { detection }\end{array}$ & $\begin{array}{l}\text { menu guided } \\
\text { configuration, } \\
\text { easy mounting }\end{array}$ \\
\hline 1004 & $\begin{array}{l}\text { ASIM } \\
\text { Technologies } \\
\text { Ltd }\end{array}$ & $\begin{array}{l}\text { TT } 260 \text { Series } \\
\text { Triple } \\
\text { technology PIR } \\
\text { / US / MW } \\
\text { detectors }\end{array}$ & $1,3,5$ & 1786 & & $\begin{array}{l}\text { count (all kinds of } \\
\text { vehicles), speed, } \\
\text { presence \& queue } \\
\text { detection, occupancy } \\
\& \text { time gap detection }\end{array}$ & 1 & 1 lane & $\begin{array}{l}\text { IP } 64 \text { splash proof, } \\
\text { mounting height, } \\
\text { detection of ghost } \\
\text { riders, detection of } \\
\text { alternating traffic, } \\
\text { self calibrating }\end{array}$ & easy mounting \\
\hline
\end{tabular}




\begin{tabular}{|c|c|c|c|c|c|c|c|c|c|c|}
\hline \multicolumn{11}{|c|}{ Video Image Processor } \\
\hline \begin{tabular}{|c|} 
Product \\
ID \\
\end{tabular} & $\begin{array}{l}\text { Company } \\
\text { Name }\end{array}$ & Mode1 Name & \begin{tabular}{|c|}
$\begin{array}{c}\text { Detector } \\
\text { Type }\end{array}$ \\
\end{tabular} & Price & Price Unit & Traffic Data & \begin{tabular}{|c|}
$\begin{array}{c}\text { Installation } \\
\text { Position }\end{array}$ \\
\end{tabular} & Coverage & $\begin{array}{c}\text { Other Main } \\
\text { Features }\end{array}$ & Any other Remarks \\
\hline 1006 & AVIAR, Inc. & $\begin{array}{l}\text { COMBI speed / } \\
\text { red light } \\
\text { system }\end{array}$ & $\begin{array}{l}\text { 6, Piezo } \\
\text { sensors }\end{array}$ & & & count, speed & $2,3,4$ & 3 lanes & $\begin{array}{l}\text { provides traffic } \\
\text { statistics such as } \\
\text { the } 85 \text { th } \\
\text { percentile, } \\
\text { average, highest } \\
\text { and lowest speeds, } \\
\text { and peak and } \\
\text { average traffic } \\
\text { flows }\end{array}$ & $\begin{array}{l}\text { used in Texas and } \\
\text { Florida, vdc-82 }\end{array}$ \\
\hline 1008 & $\begin{array}{l}\text { Computer } \\
\text { Recognition } \\
\text { Systems Inc }\end{array}$ & TAS2 & $\begin{array}{l}\text { 6-Video: } \\
\text { RS-170, } \\
\text { CCIR, } \\
\text { NTSC, PAL }\end{array}$ & 20000 & $\begin{array}{l}\text { including } \\
\text { installation }\end{array}$ & $\begin{array}{l}\text { count, speed, } \\
\text { gap, length }\end{array}$ & $\begin{array}{l}1,2 \\
\text { (permanent } \\
\text { or portable) }\end{array}$ & 32 lanes & $\begin{array}{l}\text { remote data } \\
\text { acquisition, } \\
\text { remote control \& } \\
\text { programming, } \\
\text { individual vehicle } \\
\text { records, time- } \\
\text { stamped sensor } \\
\text { events }\end{array}$ & $\begin{array}{l}\text { the system allows } \\
\text { user defined reports } \\
\& \text { user definable, } \\
\text { currently used in } \\
\text { CA, MA \& other } \\
\text { countries, } 4-16 \text { MB } \\
\text { storage capacity of } \\
\text { onsite memory }\end{array}$ \\
\hline 1009 & $\begin{array}{l}\text { Computer } \\
\text { Recognition } \\
\text { Systems Inc }\end{array}$ & NRS, NRS2 & \begin{tabular}{|l|}
$6-V i d e o$ \\
Input RS- \\
170, \\
CCIR, \\
NTSC, PAL
\end{tabular} & 20000 & $\begin{array}{l}\text { including } \\
\text { installation }\end{array}$ & $\begin{array}{l}\text { count, speed, } \\
\text { gap, travel } \\
\text { time, weigh-in- } \\
\text { motion }\end{array}$ & 1,2 & $\begin{array}{l}1-8 \\
\text { lanes }\end{array}$ & \begin{tabular}{|l|} 
remote data \\
acquisition, \\
remote control \& \\
programming, \\
individual vehicle \\
records, time- \\
stamped sensor \\
events
\end{tabular} & $\begin{array}{l}\text { the system allows } \\
\text { user defined reports } \\
\& \text { user definable, } \\
\text { currently used in } \\
\text { MA, KY, WA, LA, TA, } \\
\text { FL, and other } \\
\text { countries, 4-16 } \\
\text { Mbyte Storage } \\
\text { capacity }\end{array}$ \\
\hline 1024 & $\begin{array}{l}\text { Econolite } \\
\text { Control } \\
\text { Product, } \\
\text { Inc. }\end{array}$ & $\begin{array}{l}\text { Autoscope Solo } \\
\text { Pro MVP }\end{array}$ & 6 & 5000 & per lane & $\begin{array}{l}\text { count, speed, } \\
\text { density, }\end{array}$ & 1,2 & $\begin{array}{l}6-7 \\
\text { lanes }\end{array}$ & $\begin{array}{l}\text { integrated color } \\
\text { camera, zoom lens, } \\
\text { directional real- } \\
\text { time iris and } \\
\text { shutter speed }\end{array}$ & $\begin{array}{l}\text { rugged } \\
\text { environmentally } \\
\text { sealed enclosure, } \\
\text { failsafe mode sends } \\
\text { output to traffic }\end{array}$ \\
\hline
\end{tabular}


Video Image Processor

\begin{tabular}{|c|c|c|c|c|c|c|c|c|c|c|}
\hline \begin{tabular}{|c|} 
Product \\
ID \\
\end{tabular} & $\begin{array}{c}\text { Company } \\
\text { Name }\end{array}$ & Model Name & $\begin{array}{c}\text { Detector } \\
\text { Type }\end{array}$ & Price & Price Unit & Traffic Data & $\begin{array}{c}\text { Installation } \\
\text { Position }\end{array}$ & Coverage & $\begin{array}{c}\text { Other Main } \\
\text { Features }\end{array}$ & Any other Remarks \\
\hline & & & & & & & & & control & $\begin{array}{l}\text { control, performs } \\
\text { self test and } \\
\text { detects component } \\
\text { failure, vdc-141 }\end{array}$ \\
\hline 1025 & $\begin{array}{l}\text { Econolite } \\
\text { Control } \\
\text { Product, } \\
\text { Inc. }\end{array}$ & $\begin{array}{l}\text { Autoscope } \\
\text { 2004, ECP }\end{array}$ & 6 & 5000 & per lane & $\begin{array}{l}\text { count, gap, } \\
\text { speed }\end{array}$ & 1,2 & $\begin{array}{l}6-7 \\
\text { lanes }\end{array}$ & $\begin{array}{l}\text { available in one, } \\
\text { two, and four } \\
\text { image sensor input } \\
\text { model, Time- } \\
\text { stamped sensor } \\
\text { events }\end{array}$ & $\begin{array}{l}\text { remote data } \\
\text { acquisition, remote } \\
\text { control and } \\
\text { programming, used: } \\
\text { AZ, CA, CO, FL, IL, } \\
\text { IN, MD, MI, MN, MO, } \\
\text { NV, NJ, NM, NC, OR, } \\
\text { TX, WA, WI, vdc-141 }\end{array}$ \\
\hline 1046 & $\begin{array}{l}\text { Nestor } \\
\text { Traffic } \\
\text { Systems, } \\
\text { Inc. }\end{array}$ & RackStation $^{\mathrm{TM}}$ & 6 & & & $\begin{array}{l}\text { counts, speed, } \\
\text { vehicle } \\
\text { headway, lane } \\
\text { occupancy, lane } \\
\text { changes }\end{array}$ & - & $\begin{array}{l}4 \\
\text { cameras } \\
\text { covering } \\
6 \text { lanes } \\
\text { each }\end{array}$ & $\begin{array}{l}\text { rack mounted } \\
\text { system without the } \\
\text { added expense of } \\
\text { conditioning for } \\
\text { harsh climates, } \\
\text { Intersection and } \\
\text { Freeway } \\
\text { configurations }\end{array}$ & $\begin{array}{l}\text { supports a variety } \\
\text { of camera locations, } \\
\text { intersection and } \\
\text { freeway } \\
\text { configurations, not } \\
\text { actively marketed }\end{array}$ \\
\hline 1047 & $\begin{array}{l}\text { Nestor } \\
\text { Traffic } \\
\text { Systems, } \\
\text { Inc. }\end{array}$ & $\begin{array}{l}\text { RoadSide } \\
\text { Station }^{\mathrm{TM}}\end{array}$ & 6 & & & $\begin{array}{l}\text { counts, speed, } \\
\text { vehicle } \\
\text { headway, lane } \\
\text { occupancy, lane } \\
\text { changes }\end{array}$ & - & $\begin{array}{l}4 \\
\text { cameras } \\
\text { covering } \\
6 \text { lanes } \\
\text { each }\end{array}$ & $\begin{array}{l}\text { rack mounted } \\
\text { system equipped } \\
\text { with environmental } \\
\text { conditioning }\end{array}$ & $\begin{array}{l}\text { optional } \\
\text { surveillance package } \\
\text { can equip RoadSide } \\
\text { Station to transmit } \\
\text { live digital video } \\
\text { as well as traffic } \\
\text { data back to a } \\
\text { central monitoring } \\
\text { facility, not } \\
\text { actively marketed }\end{array}$ \\
\hline 1048 & Nestor & TOCStation ${ }^{\mathrm{TM}}$ & 6 & 12000 & or less & counts, speed, & - & 2 & no roadside & real-time traffic \\
\hline
\end{tabular}


Video Image Processor

\begin{tabular}{|c|c|c|c|c|c|c|c|c|c|c|}
\hline $\begin{array}{c}\text { Product } \\
\text { ID }\end{array}$ & $\begin{array}{l}\text { Company } \\
\text { Name }\end{array}$ & Model Name & $\begin{array}{c}\text { Detector } \\
\text { Type }\end{array}$ & Price & Price Unit & Traffic Data & $\begin{array}{c}\text { Installation } \\
\text { Position }\end{array}$ & Coverage & $\begin{array}{c}\text { Other Main } \\
\text { Features }\end{array}$ & Any other Remarks \\
\hline & $\begin{array}{l}\text { Traffic } \\
\text { Systems, } \\
\text { Inc. }\end{array}$ & & & & & lane changes & & $\begin{array}{l}\text { cameras } \\
\text { covering } \\
6 \text { lanes } \\
\text { each }\end{array}$ & $\begin{array}{l}\text { electronics, runs } \\
\text { on standard PC in } \\
\text { Traffic Operation } \\
\text { Center (TOC), }\end{array}$ & $\begin{array}{l}\text { data accessible from } \\
\text { LAN or serial ports, } \\
\text { stores data in } \\
\text { industry-standard } \\
\text { formats, functions } \\
\text { in all weather and } \\
\text { low visibility } \\
\text { conditions }\end{array}$ \\
\hline 1074 & $\begin{array}{l}\text { Peek } \\
\text { Traffic } \\
\text { Systems, } \\
\text { Inc. }\end{array}$ & VideoTrak ${ }^{\circledR-910}$ & 6 & & & $\begin{array}{l}\text { volume/counts, } \\
\text { lane occupancy, } \\
\text { speed, headway, } \\
\text { delay, queue } \\
\text { length }\end{array}$ & 2 & - & $\begin{array}{l}\text { true "wide-area" } \\
\text { detection via } \\
\text { full-scene } \\
\text { tracking, Proven } \\
\text { tracking-based } \\
\text { algorithms, Built- } \\
\text { in image } \\
\text { stabilization }\end{array}$ & $\begin{array}{l}\text { real-time video } \\
\text { information, } \\
\text { provides up to } 128 \\
\text { detection zones, } \\
\text { allows } 8 \text { video } \\
\text { inputs, } 2 \\
\text { surveillance video } \\
\text { inputs and } 2 \text { analog } \\
\text { video outputs }\end{array}$ \\
\hline 1075 & $\begin{array}{l}\text { Peek } \\
\text { Traffic } \\
\text { Systems, } \\
\text { Inc. }\end{array}$ & VideoTrak ${ }^{\circledR-905}$ & 6 & & & $\begin{array}{l}\text { volume/counts, } \\
\text { lane occupancy, } \\
\text { speed, headway, } \\
\text { delay, queue } \\
\text { length }\end{array}$ & 2 & - & $\begin{array}{l}\text { true "wide-area" } \\
\text { detection via } \\
\text { full-scene } \\
\text { tracking, Proven } \\
\text { tracking-based } \\
\text { algorithms, Built- } \\
\text { in image } \\
\text { stabilization }\end{array}$ & $\begin{array}{l}\text { real-time video } \\
\text { information, } \\
\text { provides up to } 128 \\
\text { detection zones, } \\
\text { allows } 4 \text { video } \\
\text { inputs, } 1 \\
\text { surveillance video } \\
\text { input and } 1 \text { mixed } \\
\text { analog video output }\end{array}$ \\
\hline 1092 & $\begin{array}{l}\text { Traffic } \\
\text { Systems, } \\
\text { Inc. }\end{array}$ & $\begin{array}{l}\text { Model VIP3 } \\
\text { Video Image } \\
\text { Processor, } \\
\text { Vehicle } \\
\text { Presence } \\
\text { Detector }\end{array}$ & 6 & 5000 & & $\begin{array}{l}\text { presence } \\
\text { detection, } \\
\text { counting, speed }\end{array}$ & - & 8 lanes & $\begin{array}{l}\text { available in self } \\
\text { contained stand- } \\
\text { alone units, } \\
\text { multiple functions } \\
\text { per camera, } \\
\text { Central Computer }\end{array}$ & $\begin{array}{l}\text { open error contact } \\
\text { at the absence of } \\
\text { the video signal or } \\
\text { malfunction of the } \\
\text { VIP board, easy } \\
\text { keypad or laptop }\end{array}$ \\
\hline
\end{tabular}


Video Image Processor

\begin{tabular}{|c|c|c|c|c|c|c|c|l|l|}
\hline $\begin{array}{c}\text { Product } \\
\text { ID }\end{array}$ & $\begin{array}{c}\text { Company } \\
\text { Name }\end{array}$ & Model Name & $\begin{array}{c}\text { Detector } \\
\text { Type }\end{array}$ & Price & Price Unit & Traffic Data & $\begin{array}{c}\text { Installation } \\
\text { Position }\end{array}$ & $\begin{array}{l}\text { Coverage } \\
\text { Features }\end{array}$ & $\begin{array}{l}\text { Any other Remarks } \\
\text { Frogrammable } \\
\text { programming, used : } \\
\text { Florida, Georgia, } \\
\text { vdc-153 }\end{array}$ \\
\hline
\end{tabular}

\begin{tabular}{|c|c|c|c|c|c|c|c|c|c|c|}
\hline \multicolumn{11}{|c|}{ Inductive Loop } \\
\hline \begin{tabular}{|c|} 
Product \\
ID \\
\end{tabular} & Company Name & Model Name & $\begin{array}{c}\text { Detector } \\
\text { Type }\end{array}$ & Price & Price Unit & Traffic Data & \begin{tabular}{|c|}
$\begin{array}{c}\text { Installation } \\
\text { Position }\end{array}$ \\
\end{tabular} & Coverage & $\begin{array}{c}\text { Other Main } \\
\text { Features }\end{array}$ & Any other Remarks \\
\hline 1005 & AVIAR, Inc. & TCL-300 & 7 & 5700 & $\begin{array}{l}\text { /lane, } \\
\text { Permanent } \\
\text { Temperory } \\
\$ 4500\end{array}$ & $\begin{array}{l}\text { count, time, } \\
\text { direction, } \\
\text { headway }\end{array}$ & $\begin{array}{l}3,4 \text { (on- } \\
\text { pavement) }\end{array}$ & 4 lanes & $\begin{array}{l}\text { data of } 20,000 \\
\text { individual } \\
\text { vehicles can be } \\
\text { stored into } 256 \\
\text { KB of battery- } \\
\text { powered memory, } \\
\text { used in Michigan }\end{array}$ & $\begin{array}{l}\text { vehicle data is } \\
\text { classified and } \\
\text { placed into bins } \\
\text { within the } \\
\text { instrument if a } \\
\text { recording interval } \\
\text { is selected and } \\
8,000 \text { summarized } \\
\text { data records can } \\
\text { be stored in this } \\
\text { model. vdc-69 }\end{array}$ \\
\hline 1012 & $\begin{array}{l}\text { Diamond } \\
\text { Traffic } \\
\text { Products }\end{array}$ & TT-77 & 7 & 259 & & count & 3 & 1 lane & $\begin{array}{l}\text { water-tight } \\
\text { aluminum case } \\
\text { with a lockable } \\
\text { latch, counts } \\
\text { axle or vehicle }\end{array}$ & $\begin{array}{l}8 \text { digit solid- } \\
\text { state LCD, a } \\
\text { viewing port can } \\
\text { be added so it can } \\
\text { be read without } \\
\text { opening the case }\end{array}$ \\
\hline 1015 & $\begin{array}{l}\text { Diamond } \\
\text { Traffic } \\
\text { Products }\end{array}$ & TT-21, TT-41 & 7 & 329 & & count & 3 & 1 lane & $\begin{array}{l}\text { water-tight } \\
\text { aluminum case } \\
\text { with a lockable } \\
\text { latch }\end{array}$ & $\begin{array}{l}8 \text { digit solid- } \\
\text { state LCD, TT21 } \\
\text { comes with } \\
\text { optional time } \\
\text { interval data } \\
\text { recording ability }\end{array}$ \\
\hline
\end{tabular}


Inductive Loop

\begin{tabular}{|c|c|c|c|c|c|c|c|c|c|c|}
\hline $\begin{array}{c}\text { Product } \\
\text { ID }\end{array}$ & Company Name & Model Name & $\begin{array}{l}\text { Detector } \\
\text { Type }\end{array}$ & Price & Price Unit & Traffic Data & $\begin{array}{c}\text { Installation } \\
\text { Position }\end{array}$ & Coverage & $\begin{array}{c}\text { Other Main } \\
\text { Features }\end{array}$ & Any other Remarks \\
\hline 1016 & $\begin{array}{l}\text { Diamond } \\
\text { Traffic } \\
\text { Products }\end{array}$ & $\begin{array}{l}\text { Pegasus, } \\
\text { Unicorn }\end{array}$ & $\begin{array}{l}\text { 7, } 8-\text { road } \\
\text { tube, } \\
\text { Piezos, } \\
\text { resistive } \\
\text { sensors }\end{array}$ & $\begin{array}{l}695^{-} \\
875\end{array}$ & $\begin{array}{l}\text { Pegasus } \\
\text { Unicorn } \\
\$ 1125-1345\end{array}$ & $\begin{array}{l}\text { count with } \\
\text { intervals, } \\
\text { Unicorn-speed \& } \\
\text { axle } \\
\text { classification, } \\
\text { gap, headway, and } \\
\text { speed by axle } \\
\text { type, WIM }\end{array}$ & $\begin{array}{l}4 \text { (on or in } \\
\text { pavement) }\end{array}$ & $\begin{array}{l}\text { peg: } 4 \\
\text { lanes } \\
\text { unicorn: } \\
2 \text { lanes }\end{array}$ & $\begin{array}{l}\text { time interval } \\
\text { count mode or } \\
\text { sensor count mode }\end{array}$ & $\begin{array}{l}\text { record interval } \\
\text { lengths of one } \\
\text { minute to } 24 \text { hours } \\
\text { in one minute } \\
\text { increments, } 68 \mathrm{~KB} \\
\text { of internal } \\
\text { memory, 16-key } \\
\text { watertight } \\
\text { keyboard, used: } \\
\text { CT, NY, SD, OK, } \\
\text { AL, NV }\end{array}$ \\
\hline 1017 & $\begin{array}{l}\text { Diamond } \\
\text { Traffic } \\
\text { Products }\end{array}$ & Sprite & $\begin{array}{l}7,8-\text { road } \\
\text { tube }\end{array}$ & $\begin{array}{l}475^{-} \\
725\end{array}$ & & $\begin{array}{l}\text { count with } \\
\text { intervals }\end{array}$ & $\begin{array}{l}4 \text { (on or in } \\
\text { pavement) }\end{array}$ & $\begin{array}{l}1 \text { or } 2 \\
\text { lanes }\end{array}$ & $\begin{array}{l}\text { selectable date } \\
\text { formats, cover } \\
\text { and lock } \\
\text { included, }\end{array}$ & $\begin{array}{l}\text { two lines, } 32 \\
\text { character } \\
\text { alpha/numeric LCD, } \\
99 \text { files in } 32 \mathrm{~KB} \\
\text { memory, manual or } \\
\text { automatic daily } \\
\text { file closure }\end{array}$ \\
\hline 1018 & $\begin{array}{l}\text { Diamond } \\
\text { Traffic } \\
\text { Products }\end{array}$ & $\begin{array}{l}\text { Phoenix, } \\
\text { Phoenix Rax }\end{array}$ & $\begin{array}{l}\text { 7, } 8-\text { road } \\
\text { tube, } \\
\text { Piezos, } \\
\text { fiber } \\
\text { optic, } \\
\text { radar, } \\
\text { resistive }\end{array}$ & $\begin{array}{l}1225- \\
1695\end{array}$ & & $\begin{array}{l}\text { count, speed, } \\
\text { gap, headway, } \\
\text { time stamp, } \\
\text { binned data }\end{array}$ & $\begin{array}{l}\text { 3, } 4 \text { Rax: } \\
\text { rack mounted } \\
\text { for } \\
\text { permanent } \\
\text { installation }\end{array}$ & $\begin{array}{l}\text { up to } 16 \\
\text { lanes } \\
\text { (classify } \\
\text { up to } 8 \\
\text { lanes) }\end{array}$ & $\begin{array}{l}\text { two modes of } \\
\text { count, three } \\
\text { modes of } \\
\text { classification, }\end{array}$ & $\begin{array}{l}\text { record interval } \\
\text { lengths of one } \\
\text { minute to } 24 \text { hours } \\
\text { in one minute } \\
\text { increments, } 68 \mathrm{~K} \\
\text { of counter memory, } \\
\text { 16-key watertight } \\
\text { keyboard, used: } \\
\text { FL, AL, NY, OK, } \\
\text { etc, vdc- } 80\end{array}$ \\
\hline 1020 & $\begin{array}{l}\text { Diamond } \\
\text { Traffic } \\
\text { Products }\end{array}$ & TT-14 & 7 & 339 & & count & 3 & 1 lane & $\begin{array}{l}\text { waterproof, steel } \\
\text { band and chain } \\
\text { for locking }\end{array}$ & $\begin{array}{l}8 \text { digit solid- } \\
\text { state LCD. }\end{array}$ \\
\hline
\end{tabular}


Inductive Loop

\begin{tabular}{|c|c|c|c|c|c|c|c|c|c|c|}
\hline $\begin{array}{c}\text { Product } \\
\text { ID }\end{array}$ & Company Name & Model Name & $\begin{array}{l}\text { Detector } \\
\text { Type }\end{array}$ & Price & Price Unit & Traffic Data & $\begin{array}{c}\text { Installation } \\
\text { Position }\end{array}$ & Coverage & $\begin{array}{l}\text { Other Main } \\
\text { Features }\end{array}$ & Any other Remarks \\
\hline 1021 & $\begin{array}{l}\text { Eberle Design } \\
\text { Inc. }\end{array}$ & $\begin{array}{l}\text { LM 331, LM } \\
332\end{array}$ & 7 & & & count, detection & 3 & $\begin{array}{l}2 \text { lanes-2 } \\
\text { channel, } \\
4 \text { lanes }-4 \\
\text { channel }\end{array}$ & $\begin{array}{l}\text { automatic tuning, } \\
\text { environmental } \\
\text { tracking, } 15 \text { or } \\
16 \text { levels of } \\
\text { sensitivity, } 3 \\
\text { selectable modes: } \\
\text { pulse, short } \\
\text { presence, long } \\
\text { presence }\end{array}$ & $\begin{array}{l}\text { 331: } 1 \text { channel } \\
\text { with system/count } \\
\text { output, } 332: 2 \\
\text { channel with } \\
\text { system/count } \\
\text { output, all-four } \\
\text { loop frequencies }\end{array}$ \\
\hline 1022 & $\begin{array}{l}\text { Eberle Design } \\
\text { Inc. }\end{array}$ & $\begin{array}{l}\text { LM 634, LM } \\
642\end{array}$ & 7 & & & count, detection & 3 & $\begin{array}{l}2 \text { lanes-2 } \\
\text { channel, } \\
4 \text { lanes }-4 \\
\text { channel }\end{array}$ & $\begin{array}{l}\text { automatic tuning, } \\
\text { environmental } \\
\text { tracking, } 15 \\
\text { levels of } \\
\text { sensitivity, } 3 \\
\text { selectable modes: } \\
\text { pulse, short } \\
\text { presence, long } \\
\text { presence }\end{array}$ & $\begin{array}{l}2 \text { channel, } 4 \text { loop } \\
\text { frequencies }\end{array}$ \\
\hline 1023 & $\begin{array}{l}\text { Eberle Design } \\
\text { Inc. }\end{array}$ & Oracle /2 & 7 & & & detection & 3 & $\begin{array}{l}2 \text { lanes-2 } \\
\text { channel, } \\
4 \text { lanes }-4 \\
\text { channel }\end{array}$ & $\begin{array}{l}\text { LCD display of } \\
\text { operational and } \\
\text { diagnostic } \\
\text { information, } 15 \\
\text { levels of } \\
\text { sensitivity, } 3 \\
\text { selectable modes }\end{array}$ & $\begin{array}{l}2 \text { channel, } 8 \text { loop } \\
\text { frequencies }\end{array}$ \\
\hline 1033 & $\begin{array}{l}\text { JAMAR } \\
\text { Technologies, } \\
\text { Inc. }\end{array}$ & $\begin{array}{l}\text { TRAX III } \\
\text { Automatic } \\
\text { Traffic } \\
\text { Recorder }\end{array}$ & $\begin{array}{l}\text { 7, 8-road } \\
\text { tube, } \\
\text { Piezo }\end{array}$ & \begin{tabular}{|l|}
$1395-$ \\
1595
\end{tabular} & & $\begin{array}{l}\text { volume, speed, } \\
\text { gap, length, } \\
\text { binned data per- } \\
\text { vehicle }\end{array}$ & $\begin{array}{l}3,4 \text { (on } \\
\text { road) }\end{array}$ & 1-8 lanes & $\begin{array}{l}\text { real-time \& date } \\
\text { clock, } \\
\text { programmable } \\
\text { intervals, } 2 \text { to } 4 \\
\text { loop inputs, } 2 \text { or } \\
4 \text { road tube } \\
\text { inputs available, }\end{array}$ & $\begin{array}{l}\text { cast aluminum } \\
\text { housing, full } \\
\text { numeric keypad, } \\
\text { four line LCD } \\
\text { display, FHWA or } \\
\text { custom } \\
\text { classification, }\end{array}$ \\
\hline
\end{tabular}


Inductive Loop

\begin{tabular}{|c|c|c|c|c|c|c|c|c|c|c|}
\hline \begin{tabular}{|c|} 
Product \\
ID \\
\end{tabular} & Company Name & Model Name & $\begin{array}{c}\text { Detector } \\
\text { Type }\end{array}$ & Price & Price Unit & Traffic Data & \begin{tabular}{|c|}
$\begin{array}{c}\text { Installation } \\
\text { Position }\end{array}$ \\
\end{tabular} & Coverage & $\begin{array}{c}\text { Other Main } \\
\text { Features }\end{array}$ & Any other Remarks \\
\hline & & & & & & & & & $\begin{array}{l}\text { optional solar } \\
\text { panel }\end{array}$ & $\begin{array}{l}1024 \mathrm{~KB} \text { internal } \\
\text { memory }\end{array}$ \\
\hline 1034 & $\begin{array}{l}\text { JAMAR } \\
\text { Technologies, } \\
\text { Inc. }\end{array}$ & $\begin{array}{l}\text { TRAX } \\
\text { TOTALIZER } \\
\text { Automatic } \\
\text { Traffic } \\
\text { Recorder }\end{array}$ & $\begin{array}{l}7,8-\text { road } \\
\text { tube }\end{array}$ & $\begin{array}{l}375^{-} \\
535\end{array}$ & & $\begin{array}{l}\text { volume, speed, } \\
\text { gap, length }\end{array}$ & $\begin{array}{l}3,4 \text { (on } \\
\text { road) }\end{array}$ & 1-8 lanes & $\begin{array}{l}1 \text { or } 2 \text { road tube } \\
\text { inputs, } 1 \text { or } 2 \\
\text { loop inputs, }\end{array}$ & $\begin{array}{l}\text { cast aluminum } \\
\text { housing, able to } \\
\text { record data } \\
\text { without the need } \\
\text { to download to a } \\
\text { computer, LCD } \\
\text { display, } \\
\text { reviewable totals } \\
\text { during or after } \\
\text { count }\end{array}$ \\
\hline 1043 & $\begin{array}{l}\text { Mitron } \\
\text { Systems } \\
\text { Corporation }\end{array}$ & $\begin{array}{l}\text { MSC4000 } \\
\text { Scout system }\end{array}$ & $\begin{array}{l}\text { 7, } 8 \text {-road } \\
\text { tube or } \\
\text { Piezo }\end{array}$ & 1599 & $\begin{array}{l}\text { permanent. } \\
\text { Portable: } \\
\$ 1779\end{array}$ & $\begin{array}{l}\text { count, speed, } \\
\text { gap, headway }\end{array}$ & $\begin{array}{l}3,4 \\
\text { (portable } \\
\text { and } \\
\text { permanent) }\end{array}$ & 20 lanes & $\begin{array}{l}\text { 20-channel } \\
\text { modular traffic } \\
\text { recorder, rack- } \\
\text { mount or } \\
\text { portable, } \\
\text { multiple studies } \\
\text { performed } \\
\text { simultaneously }\end{array}$ & $\begin{array}{l}\text { time-stamped } \\
\text { sensor events, } \\
\text { waterproof } \\
\text { connectors, real- } \\
\text { time } \\
\text { clock/calendar, } \\
\text { multiple studies } \\
\text { performed } \\
\text { simultaneously }\end{array}$ \\
\hline 1049 & $\begin{array}{l}\text { Never-Fail } \\
\text { Loop Systems, } \\
\text { Inc. }\end{array}$ & $\begin{array}{l}\text { Model A } \\
\text { (Asphalt } \\
\text { overlay) }\end{array}$ & 7 & & & - & 3 & - & $\begin{array}{l}\text { patented } \\
\text { expansion / } \\
\text { contraction } \\
\text { joints, Direct } \\
\text { burial into sub- } \\
\text { base or tie down } \\
\text { to rebar }\end{array}$ & - \\
\hline 1050 & $\begin{array}{l}\text { Never-Fail } \\
\text { Loop Systems, } \\
\text { Inc. }\end{array}$ & $\begin{array}{l}\text { Model F-38 } \\
\text { (A11 above - } \\
\text { plus }\end{array}$ & 7 & & & - & 3 & - & $\begin{array}{l}\text { needs only a } 3 / 8^{\prime \prime} \\
(9.5 \mathrm{~mm}) \text { saw-cut } \\
\text { slot, Patented }\end{array}$ & - \\
\hline
\end{tabular}


Inductive Loop

\begin{tabular}{|c|c|c|c|c|c|c|c|c|c|c|}
\hline $\begin{array}{c}\text { Product } \\
\text { ID }\end{array}$ & Company Name & Model Name & $\begin{array}{l}\text { Detector } \\
\text { Type }\end{array}$ & Price & Price Unit & Traffic Data & $\begin{array}{c}\text { Installation } \\
\text { Position }\end{array}$ & Coverage & $\begin{array}{l}\text { Other Main } \\
\text { Features }\end{array}$ & Any other Remarks \\
\hline & & temporary) & & & & & & & $\begin{array}{l}\text { expansion / } \\
\text { contraction } \\
\text { capabilities }\end{array}$ & \\
\hline 1051 & $\begin{array}{l}\text { Never-Fai1 } \\
\text { Loop Systems, } \\
\text { Inc. }\end{array}$ & $\begin{array}{l}\text { Model C } \\
\text { (Concrete } \\
\text { overlay) }\end{array}$ & 7 & & & - & 3 & - & $\begin{array}{l}\text { patented } \\
\text { expansion / } \\
\text { contraction } \\
\text { joints, Direct } \\
\text { burial into sub- } \\
\text { base or tie down } \\
\text { to rebar }\end{array}$ & - \\
\hline 1052 & $\begin{array}{l}\text { Never-Fail } \\
\text { Loop Systems, } \\
\text { Inc. }\end{array}$ & $\begin{array}{l}\text { Model F } \\
\text { (Cut-in } \\
\text { application) }\end{array}$ & 7 & & & - & 3,4 & - & $\begin{array}{l}\text { Patented } \\
\text { expansion / } \\
\text { contraction } \\
\text { joints }\end{array}$ & - \\
\hline 1067 & $\begin{array}{l}\text { Peek Traffic } \\
\text { Inc- } \\
\text { Components }\end{array}$ & JR 161 & 7 & & & count & 4 & - & - & $\begin{array}{l}\text { padlock with } 2 \\
\text { keys }\end{array}$ \\
\hline 1072 & $\begin{array}{l}\text { Peek Traffic } \\
\text { Inc- } \\
\text { Components }\end{array}$ & $\begin{array}{l}\text { Idris Smart } \\
\text { Loops }\end{array}$ & 7 & & & $\begin{array}{l}\text { count, lane } \\
\text { designation }\end{array}$ & 2 & 8 lanes & $\begin{array}{l}\text { capable of } \\
\text { differentiation } \\
\text { between two } \\
\text { vehicles } \\
\text { tailgating and a } \\
\text { single vehicle } \\
\text { towing a trailer }\end{array}$ & $\begin{array}{l}\text { up to } 16 \text { inductive } \\
\text { loop inputs, in a } \\
\text { multi0lane } \\
\text { environment, lane- } \\
\text { straddling } \\
\text { vehicles are } \\
\text { distinguished from } \\
\text { those traveling } \\
\text { similar speeds in } \\
\text { adjacent lanes, } \\
\text { vdc-45 }\end{array}$ \\
\hline 1076 & Reno A \& E & $\begin{array}{l}\text { Model G/222 } \\
\text { Series }\end{array}$ & 7 & 146 & & count & - & - & $\begin{array}{l}\text { two detector's } \\
\text { channels in a } \\
\text { single unit, } 8\end{array}$ & $\begin{array}{l}\text { lightning } \\
\text { protection, red, } \\
\text { high intensity LED }\end{array}$ \\
\hline
\end{tabular}


Inductive Loop

\begin{tabular}{|c|c|c|c|c|c|c|c|c|c|c|}
\hline $\begin{array}{c}\text { Product } \\
\text { ID }\end{array}$ & Company Name & Model Name & $\begin{array}{c}\text { Detector } \\
\text { Type }\end{array}$ & Price & Price Unit & Traffic Data & $\begin{array}{c}\text { Installation } \\
\text { Position }\end{array}$ & Coverage & $\begin{array}{c}\text { Other Main } \\
\text { Features }\end{array}$ & Any other Remarks \\
\hline & & & & & & & & & $\begin{array}{l}\text { levels of } \\
\text { sensitivity per } \\
\text { channel, two } \\
\text { selectable output } \\
\text { modes per channel }\end{array}$ & $\begin{array}{l}\text { DETECT and Loop } \\
\text { FAIL indicators, } \\
\text { 2-channel rack } \\
\text { mount type }\end{array}$ \\
\hline 1077 & Reno A \& E & $\begin{array}{l}\text { Model L } \\
\text { series }\end{array}$ & 7 & 149 & & count & - & - & $\begin{array}{l}\text { accumulated } \\
\text { number of Loop } \\
\text { Failures since } \\
\text { the detector was } \\
\text { last reset, }\end{array}$ & $\begin{array}{l}\text { custom "Back- } \\
\text { lit” LCD screen } \\
\text { displays the } \\
\text { complete status } \\
\text { and function } \\
\text { settings of the } \\
\text { detector, 1- } \\
\text { channel shelf } \\
\text { mount type }\end{array}$ \\
\hline 1078 & Reno A \& E & $\begin{array}{l}\text { Model C } \\
\text { Series, }\end{array}$ & 7 & 215 & & count & - & - & $\begin{array}{l}\text { automatically } \\
\text { tunes and is } \\
\text { operational } \\
\text { within } 2 \text { seconds } \\
\text { after application } \\
\text { of power or after } \\
\text { being reset, } \\
\text { directional logic }\end{array}$ & $\begin{array}{l}\text { LCD display, } \\
\text { built-in audible } \\
\text { detect buzzer, } \\
\text { third car passage } \\
\text { logic, 2-channel } \\
\text { rack mount type }\end{array}$ \\
\hline 1079 & Reno A \& E & $\begin{array}{l}\text { Model U } \\
\text { series }\end{array}$ & 7 & 388 & & count & - & - & $\begin{array}{l}\text { phase green loop } \\
\text { compensation, } \\
\text { phase green } \\
\text { inputs for all } \\
\text { channels, } \\
\text { directional logic }\end{array}$ & $\begin{array}{l}\text { custom "Back- } \\
\text { lit" LCD screen } \\
\text { displays the } \\
\text { complete status } \\
\text { and function } \\
\text { settings of the } \\
\text { detector, 4- } \\
\text { channel shelf } \\
\text { mount type }\end{array}$ \\
\hline
\end{tabular}


Inductive Loop

\begin{tabular}{|c|c|c|c|c|c|c|c|c|c|c|}
\hline \begin{tabular}{|c|} 
Product \\
ID \\
\end{tabular} & Company Name & Model Name & $\begin{array}{c}\text { Detector } \\
\text { Type }\end{array}$ & Price & Price Unit & Traffic Data & $\begin{array}{c}\text { Installation } \\
\text { Position }\end{array}$ & Coverage & $\begin{array}{c}\text { Other Main } \\
\text { Features }\end{array}$ & Any other Remarks \\
\hline 1080 & Reno A \& E & $\begin{array}{l}\text { Model T } \\
\text { Series }\end{array}$ & 7 & 100 & & count & - & - & $\begin{array}{l}\text { external DIP } \\
\text { switch for } \\
\text { setting } \\
\text { parameters }\end{array}$ & $\begin{array}{l}1 \text { channel shelf } \\
\text { mount type, solid } \\
\text { state or relay } \\
\text { versions. }\end{array}$ \\
\hline 1081 & Reno A \& E & $\begin{array}{l}\text { Model E } \\
\text { Series }\end{array}$ & 7 & 329 & & count & - & - & $\begin{array}{l}\text { built-in audible } \\
\text { detect buzzer, } \\
\text { phase green loop } \\
\text { compensation, } \\
\text { directional logic }\end{array}$ & $\begin{array}{l}\text { custom "Back- } \\
\text { lit" LCD screen } \\
\text { displays the } \\
\text { complete status } \\
\text { and function } \\
\text { settings of the } \\
\text { detector, 4- } \\
\text { channel rack mount } \\
\text { type }\end{array}$ \\
\hline 1082 & Reno A \& E & $\begin{array}{l}\text { Model S } \\
\text { Series }\end{array}$ & 7 & 279 & & count & - & - & $\begin{array}{l}\text { phase green loop } \\
\text { compensation, } \\
\text { directional } \\
\text { logic, }\end{array}$ & $\begin{array}{l}\text { custom "Back- } \\
\text { lit" LCD screen } \\
\text { displays the } \\
\text { complete status } \\
\text { and function } \\
\text { settings of the } \\
\text { detector, 2- } \\
\text { channel shelf } \\
\text { mount type }\end{array}$ \\
\hline 1093 & $\begin{array}{l}\text { U. S. Traffic } \\
\text { Corporation } \\
\text { Manufacturers } \\
\& \text { System } \\
\text { Engineers }\end{array}$ & $919 A$ & 7 & 250 & $\begin{array}{l}\text { per lane } \\
\text { installation: } \\
\$ 750\end{array}$ & count & 3 & 1 lane & $\begin{array}{l}\text { ten levels of } \\
\text { sensitivity, over } \\
\text { an extended } \\
\text { range, self- } \\
\text { tuning and } \\
\text { complete } \\
\text { environmental } \\
\text { tracking }\end{array}$ & $\begin{array}{l}\text { red, high } \\
\text { intensity LED } \\
\text { Detect indicator, } \\
\text { used: nationwide }\end{array}$ \\
\hline 1094 & U.S. Traffic & $272 \mathrm{M}$ & 7 & 311 & per lane. & count & 3 & 2 lanes & eight levels of & red, high \\
\hline
\end{tabular}


Inductive Loop

\begin{tabular}{|c|c|c|c|c|c|c|c|c|c|c|}
\hline $\begin{array}{c}\text { Product } \\
\text { ID }\end{array}$ & Company Name & Mode1 Name & $\begin{array}{c}\text { Detector } \\
\text { Type }\end{array}$ & Price & Price Unit & Traffic Data & $\begin{array}{c}\text { Installation } \\
\text { Position }\end{array}$ & Coverage & $\begin{array}{c}\text { Other Main } \\
\text { Features }\end{array}$ & Any other Remarks \\
\hline & $\begin{array}{l}\text { Corporation } \\
\text { Manufacturers } \\
\& \text { System } \\
\text { Engineers }\end{array}$ & & & & $\begin{array}{l}\text { Installation: } \\
\$ 750\end{array}$ & & & & $\begin{array}{l}\text { sensitivity per } \\
\text { channel, self-- } \\
\text { tuning and } \\
\text { complete } \\
\text { environmental } \\
\text { tracking }\end{array}$ & $\begin{array}{l}\text { intensity LED } \\
\text { DETECT indicator, } \\
\text { used: nationwide }\end{array}$ \\
\hline 1095 & $\begin{array}{l}\text { U. S. Traffic } \\
\text { Corporation } \\
\text { Manufacturers } \\
\& \text { System } \\
\text { Engineers }\end{array}$ & IVS 200 & 7 & 3000 & $\begin{array}{l}\text { per lane } \\
\text { Instation: } \\
\$ 750-1500\end{array}$ & gap, headway & - & - & $\begin{array}{l}\text { operates with } \\
\text { existing loops, } \\
\text { self-tuning and } \\
\text { completely } \\
\text { environmental } \\
\text { tracking, } \\
\text { automatic } \\
\text { switchover from } \\
\text { two to one loop }\end{array}$ & $\begin{array}{l}\text { red, high } \\
\text { intensity LED } \\
\text { light signals } \\
\text { vehicle over loop, } \\
\text { four frequencies } \\
\text { per loop, faulty } \\
\text { loop indicator }\end{array}$ \\
\hline 1096 & $\begin{array}{l}\text { MetroCount } \\
\text { (USA) Inc. }\end{array}$ & \begin{tabular}{|l} 
DB-100 \\
Turning \\
Movement \\
Counter
\end{tabular} & 7 & & & & & & & \\
\hline 1097 & $\begin{array}{l}\text { MetroCount } \\
\text { (USA) Inc. }\end{array}$ & $\begin{array}{l}\text { DB-400 } \\
\text { Turning } \\
\text { Movement } \\
\text { Counter }\end{array}$ & 7 & & & & & & & \\
\hline 1098 & $\begin{array}{l}\text { MetroCount } \\
\text { (USA) Inc. }\end{array}$ & $\begin{array}{l}\text { TDC-8 } \\
\text { Traffic Data } \\
\text { Collector }\end{array}$ & 7 & & & $\begin{array}{l}\text { turning } \\
\text { movements, } \\
\text { classification, } \\
\text { gap, intersection } \\
\text { stop delay, stop } \\
\text { sign delay, spot } \\
\text { speed with class, } \\
\text { travel time and }\end{array}$ & & & & \\
\hline
\end{tabular}


Inductive Loop

\begin{tabular}{|c|c|c|c|c|c|c|c|c|c|c|}
\hline $\begin{array}{c}\text { Product } \\
\text { ID }\end{array}$ & Company Name & Model Name & $\begin{array}{c}\text { Detector } \\
\text { Type }\end{array}$ & Price & Price Unit & Traffic Data & $\begin{array}{c}\text { Installation } \\
\text { Position }\end{array}$ & Coverage & $\begin{array}{c}\text { Other Main } \\
\text { Features }\end{array}$ & Any other Remarks \\
\hline & & & & & & delay & & & & \\
\hline
\end{tabular}


Appendix B: Vendor Information 


\begin{tabular}{|c|c|c|c|c|c|}
\hline \multicolumn{6}{|c|}{ Vendor } \\
\hline \begin{tabular}{|c|}
$\begin{array}{c}\text { Vendor } \\
\text { ID }\end{array}$ \\
\end{tabular} & Company Name & Address & Phone & E-mail & URL \\
\hline 100 & $\begin{array}{l}\text { 3M, Intelligent } \\
\text { Transportation Systems }\end{array}$ & & \begin{tabular}{|lrr}
1 & $(800)$ & $927-5476$ \\
Robert & L. & Dreger
\end{tabular} & & http://www. 3m. com/its/ \\
\hline 101 & ASIM Technologies Ltd & $\begin{array}{l}\text { Ziegelhof-Strasse } 30 \mathrm{CH}-8730 \\
\text { Uznach Switzerland }\end{array}$ & $+41-55-2859999$ & mguentensperger@asim.ch & http://www. asim-technologies. com \\
\hline 102 & AVIAR, Inc. & $\begin{array}{l}\text { P0 Box } 162184 \text { Austin, TX } \\
78716 \text { USA }\end{array}$ & $1 \quad(512) \quad 295-5285$ & sales@aviarinc.com & http://www. aviarinc. com/ \\
\hline 103 & $\begin{array}{l}\text { Computer Expertise } \\
\text { Corp. }\end{array}$ & $\begin{array}{l}\text { P0 Box } 1899 \text { North Windham, } \\
\text { Me. } 04062 \text { USA }\end{array}$ & $1(207) \quad 892-0740$ & $\begin{array}{l}\text { cecorp@computerexpertise.co } \\
m\end{array}$ & http://www. computerexpertise. com/ \\
\hline 104 & $\begin{array}{l}\text { Computer Recognition } \\
\text { Systems Inc }\end{array}$ & $\begin{array}{l}625 \text { Massachusetts Avenue, } \\
\text { Suite } 5 \text { Cambridge MA } 02139 \\
\text { USA }\end{array}$ & $1 \quad(617) \quad 491-7665$ & info@crs-its.com & http://www. crs-vision. com/ \\
\hline 105 & $\begin{array}{l}\text { Diamond Traffic } \\
\text { Products }\end{array}$ & $\begin{array}{l}\text { P. 0. Box } 1455 \text { Oakridge, OR } \\
97463 \text { USA }\end{array}$ & 1 (541) 782-3903 & diamondtrf@aol.com & http://www. diamondtraffic. com \\
\hline 106 & Eberle Design Inc. & $\begin{array}{l}3819 \text { East La Salle Street } \\
\text { Phoenix, AZ } 85040 \text { USA }\end{array}$ & $1 \quad(480) \quad 968-6407$ & info@editraffic.com & http://www. editraffic. com/ \\
\hline 107 & $\begin{array}{l}\text { Econolite Control } \\
\text { Product, Inc. }\end{array}$ & $\begin{array}{l}3360 \text { East La Palma Ave. } \\
\text { Anaheim, CA } 92806 \text { USA }\end{array}$ & $1 \quad(714) \quad 630-3700$ & info@econolite.com & http://www. econolite. com/ \\
\hline 108 & $\begin{array}{l}\text { EIS, Electronic } \\
\text { Integrated Systems Inc. }\end{array}$ & $\begin{array}{l}150 \text { Bridgeland Ave. \#204 } \\
\text { Toronto, M6A 1Z5 Canada }\end{array}$ & 1 (416) 785-9248 & sales@rtms-by-eis.com & http://www. rtms-by-eis.com/ \\
\hline 109 & $\begin{array}{l}\text { Electronic Control } \\
\text { Measurement Inc. }\end{array}$ & $\begin{array}{l}\text { P. 0. Box 888, Manor, Texas } \\
78653 \text { USA }\end{array}$ & $1 \quad(512) 2724346$ & ecmusa@io.com & http://www. ecm-france. com/ \\
\hline 110 & $\begin{array}{l}\text { Golden River Traffic, } \\
\text { Ltd. (Jamar in US) }\end{array}$ & $\begin{array}{l}\text { Churchil1 Road Bicester, } \\
\text { 0xfordshire 0X26 4XT United } \\
\text { Kingdom }\end{array}$ & $\begin{array}{l}+44-(0) 1869- \\
362800\end{array}$ & infor@goldenriver.com & http://www. goldenriver. com \\
\hline 111 & $\begin{array}{l}\text { JAMAR Technologies, } \\
\text { Inc. }\end{array}$ & $\begin{array}{l}151 \text { Keith Valley Road } \\
\text { Horsham, PA 19044-1411 USA }\end{array}$ & $\begin{array}{|lll|}1 & (800) & 776-0940 \\
1 & (215) & 491-4899\end{array}$ & mai1@jamartech.com & http://www. jamartech. com/ \\
\hline 112 & MetroCount (USA) Inc. & $\begin{array}{l}\text { 17130 Moss Side Lane 01ney, } \\
\text { MD 20832-2937 USA }\end{array}$ & $\begin{array}{|lll|}1 & (800) & 576-5692 \\
1 & (301) & 570-2800\end{array}$ & USAsales@metrocount.com & http://www. metrocount. com/ \\
\hline
\end{tabular}




\begin{tabular}{|c|c|c|c|c|c|c|}
\hline \multicolumn{7}{|c|}{ Vendor } \\
\hline \begin{tabular}{|c|} 
Vendor \\
ID
\end{tabular} & Company Name & Address & Pho & one & E-mail & URL \\
\hline 113 & Microwave Sensors, Inc & $\begin{array}{l}7885 \text { Jackson Road Ann Arbor } \\
\text { Michigan } 48103 \text { USA }\end{array}$ & $1 \& 734)$ & $426-0140$ & $\begin{array}{l}\text { bhunter@microwavesensors. co } \\
\text { m }\end{array}$ & http://microwavesensors.com/ \\
\hline 114 & $\begin{array}{l}\text { Midian Electronics, } \\
\text { Inc. }\end{array}$ & & $1 \quad(520) 8$ & $884-7981$ & sales@midelec.com & http://www. dp105. net/partners/midian. \\
\hline 115 & $\begin{array}{l}\text { Mitron Systems } \\
\text { Corporation }\end{array}$ & $\begin{array}{l}\text { 9130-U Red Branch Road } \\
\text { Columbia, Maryland } 21045 \text { USA }\end{array}$ & $\begin{array}{lll}1 & (800) & 6 \\
1 & (410) & 9\end{array}$ & $\begin{array}{l}638-9665 \\
992-7700\end{array}$ & support@mitronsystems.com & http://www. mitronsystems. com/ \\
\hline 116 & $\begin{array}{l}\text { Nestor Traffic Systems, } \\
\text { Inc. }\end{array}$ & $\begin{array}{l}\text { One Richmond Square } \\
\text { Providence, RI } 02906 \text { USA }\end{array}$ & $1 \quad(401) 3$ & $331-9640$ & dwalker@nestor.com & http://www. nestor. com/nts/default. htm \\
\hline 117 & $\begin{array}{l}\text { Never-Fail Loop } \\
\text { Systems, Inc. }\end{array}$ & $\begin{array}{l}7911 \text { NE 33rd Drive, Unit } 160 \\
\text { Portland, OR 97211 USA }\end{array}$ & $1 \quad(503) 4$ & $408-9248$ & general@neverfail.com & http://home. pacifier. com/ nfls/ \\
\hline 118 & $\begin{array}{l}\text { Novax Industries } \\
\text { Corporation }\end{array}$ & $\begin{array}{l}658 \text { Derwent Way New } \\
\text { Westminster, B. C., V3M 5P8 } \\
\text { Canada }\end{array}$ & $1 \quad(604) 5$ & $525-5644$ & heather_h@novax.com & http://www. novax. com/ \\
\hline 119 & $\begin{array}{l}\text { Nu-Metrics, Inc }-\mathrm{A} \\
\text { Quixote Company }\end{array}$ & $\begin{array}{l}518 \text { University Drive } \\
\text { Uniontown, PA } 15401 \text { USA }\end{array}$ & $1 \quad(724) 4$ & $438-8750$ & sales@nu-metrics.com & http://www. nu-metrics. com/ \\
\hline 120 & PAT America, Inc. & $\begin{array}{l}2402 \text { Spring Ridge Dr. Suite E } \\
\text { Spring Grove, IL } 60081 \text { USA }\end{array}$ & $\begin{array}{lll}1 & (877) & 8 \\
1 & (815) & 6\end{array}$ & $\begin{array}{l}862-6868 \\
675-1430 \\
\end{array}$ & info@patamerica.com & http://internationaltraffic. com/ \\
\hline 121 & $\begin{array}{l}\text { Peek Traffic Inc- } \\
\text { Components }\end{array}$ & $\begin{array}{l}1500 \text { N. Washington Blvd. } \\
\text { Sarasota, FL } 34236 \text { USA }\end{array}$ & $\begin{array}{lll}1 & (800) & 2 \\
1 & (941) & 3\end{array}$ & $\begin{array}{l}245-7660 \\
366-8770 \\
\end{array}$ & Pkeen@peektrafficinc.com & $\begin{array}{l}\text { http://www. peektrafficinc. com/cover. } h \\
\text { tm }\end{array}$ \\
\hline 122 & $\begin{array}{l}\text { Peek Traffic Systems, } \\
\text { Inc. }\end{array}$ & $\begin{array}{l}3000 \text { Commonwealth Blvd. } \\
\text { Tallahassee, FL } 32303 \text { USA }\end{array}$ & $\begin{array}{lll}1 & (877) & 4 \\
1 & (850) & 5\end{array}$ & $\begin{array}{l}\text { 490-PEEK } \\
562-2253\end{array}$ & info@peek-traffic.com & http://www. peek-traffic. com/ptsi/ \\
\hline 123 & Reno A \& E & $\begin{array}{l}4655 \text { Aircenter Circle Reno, } \\
\text { NV } 89502 \text { USA }\end{array}$ & $1 \quad(775) 8$ & $826-2020$ & sales@renoae.com & http://www. renoae. com/ \\
\hline 124 & $\begin{array}{l}\text { Schwartz Electro- } \\
\text { Optics, Inc. }\end{array}$ & $\begin{array}{l}3404 \text { N. Orange Blossom Trail } \\
\text { Orlando, Florida } 32804 \text { USA }\end{array}$ & $1 \quad(407) 2$ & $298-1802$ & customerservice@seo.com & http://www. seord. com/ \\
\hline 125 & $\begin{array}{l}\text { Scientific } \\
\text { Technologies, Inc. }\end{array}$ & $\begin{array}{l}6550 \text { Dumbarton Circle } \\
\text { Fremont, CA 94555-3611 USA }\end{array}$ & $\begin{array}{lll}1 & (800) & 2 \\
1 & (510) & 6\end{array}$ & $\begin{array}{l}221-7060 \\
608-3400\end{array}$ & sales@sti.com & http://www. sti.com/ \\
\hline 126 & SmarTek Systsms, Inc. & $\begin{array}{l}\text { 14710 Kogan Drive Woodbridge, } \\
\text { VA } 22193 \text { USA }\end{array}$ & $1(410) 3$ & $315-9727$ & sales@smarteksys.com & http://www. smarteksys. com/ \\
\hline
\end{tabular}




\begin{tabular}{|c|c|c|c|c|c|}
\hline \multicolumn{6}{|c|}{ Vendor } \\
\hline $\begin{array}{l}\text { Vendor } \\
\text { ID }\end{array}$ & Company Name & Address & Phone & E-mail & URL \\
\hline 127 & Spectra Research, Inc. & $\begin{array}{l}3085 \text { Woodman Drive Dayton, OH } \\
45420-1173 \text { USA }\end{array}$ & $1 \quad(937)$ 299-5999 & sstarr@spectra-research.com & http://www. spectra-research.com/ \\
\hline 128 & TimeMark, Inc. & $\begin{array}{l}\text { P0 Box } 12947 \text { Salem, OR } 97309 \\
\text { USA }\end{array}$ & $1 \quad(800) \quad 755-5882$ & Sales@TimeMarkInc. com & http://www. timemarkinc. com/Intro. html \\
\hline 129 & Traffic Systems, Inc. & $\begin{array}{l}337 \text { Skidmore Road Deer Park } \\
\text { New York, } 11729 \text { USA }\end{array}$ & 1 (516) 242-4292 & Rich@trafficsystemsinc.com & http://www. trafficsystemsinc. com/ \\
\hline 130 & $\begin{array}{l}\text { U. S. Traffic } \\
\text { Corporation } \\
\text { Manufacturers \& System } \\
\text { Engineers }\end{array}$ & $\begin{array}{l}9603 \text { John Street Santa Fe } \\
\text { Springs, CA } 90670 \text { USA }\end{array}$ & $\begin{array}{|lll|}1 & (800) & 733-7872 \\
1 & (562) & 923-9600\end{array}$ & $\begin{array}{l}\text { customer. service@idc- } \\
\text { traffic.com }\end{array}$ & http://www. idc-traffic. com/ \\
\hline 131 & $\begin{array}{l}\text { International Traffic } \\
\text { Co }\end{array}$ & $\begin{array}{l}2402 \text { SpringRidge Drive Spring } \\
\text { Grove, IL } 60081\end{array}$ & $815-675-1430$ & ticsfo@ticsfo.co & http:// www. ticsfo. com \\
\hline
\end{tabular}


Appendix C: User Survey 
July, 2001

Dear Sir/Madam,

We are working on an Indiana Department of Transportation project to evaluate traffic counting devices currently available in the market. Due to the fast-changing technological developments in this area, and a wide range of standards and technologies, there is a need to develop a systematic mechanism to evaluate traffic counting devices to aid future purchase decisions. This survey seeks your opinion on your experience with various traffic counting devices that are being used in your state or district. We would greatly appreciate it if you could take a few minutes to complete this brief survey.

Srinivas Peeta, Associate Professor, Ph.D.

Pengcheng Zhang, Ph.D. Candidate

David Burkett, Undergraduate Intern

School of Civil Engineering, Purdue University

West Lafayette, IN 47907

1. Personal information (optional):

1) Name:

2) Employer:

3) Position:

4) Work Type (mark one): Operations

Research Planning

Other

5) Years of Experience in Traffic Data Collection/Traffic Counting Devices:

2. How would you rate the following factors when purchasing traffic counting devices?

(1 being the most important factor, and 10 being the least important factor)

Price

Accuracy

Durability

Reliability

Portability

Ease of Data Retrieval

Ease of Installation

Functionality

Less Personnel Retraining Needs

Maintenance Requirements

3. What traffic related data is generally needed in your work? Do your current traffic counting devices match the needs? 
4. Evaluation of the traffic counting devices being used in your state/district.

Please answer the following questions for each product.

(a) How would you rate the traffic counting device? (A-Excellent, B-Good, C-Average, D-Poor, E-Very poor)

(b) What data can the device collect? (1-vehicle counting, 2-volume, 3-vehicle speeds, 4-lane occupancy, 5-gap \& headway, 6-vehicle classification, 7-vehicle identification, 8-weather and environment, 9-other, please specify.)

\section{Product 1:}

Vendor/Model

(a) Overall Accuracy

Reliability

Lifecycle Costs

Training Requirements

Ease of Installation/Maintenance

(b) Data Collection

(c) Other Remarks

Product 2:

Vendor/Model

(a) Overall Accuracy

Reliability

Lifecycle Costs

Training Requirements

Ease of Installation/Maintenance

(b) Data Collection

(c) Other Remarks

Product 3:

Vendor/Model

(a) Overall

Accuracy

Reliability

Lifecycle Costs

Training Requirements

Ease of Installation/Maintenance

(b) Data Collection

(c) Other Remarks

\section{Thank you for your time!! We really appreciate it.}


Appendix D: Product Evaluation 


\begin{tabular}{|c|c|c|c|c|c|c|c|c|c|}
\hline \multicolumn{10}{|c|}{ Product Evaluation } \\
\hline ID & $\begin{array}{l}\text { Product } \\
\text { ID }\end{array}$ & Mode1 & $\begin{array}{l}\text { Overall } \\
\text { Grade }\end{array}$ & Accuracy & Reliability & Cost & $\begin{array}{c}\text { Training } \\
\text { Requirements }\end{array}$ & $\begin{array}{c}\text { Ease of } \\
\text { Installation/Maintenance }\end{array}$ & 0ther Remarks \\
\hline 1 & 1018 & DIAMOND & B & $\mathrm{B}$ & B & $\mathrm{C}$ & $\mathrm{C}$ & $\mathrm{C}$ & expensive but solid and reliable \\
\hline 2 & 1018 & DIAMOND & $\mathrm{C}$ & B & $\mathrm{D}$ & $\mathrm{C}$ & B & B & \\
\hline 3 & 1018 & DIAMOND PHOENIX & $\mathrm{C}$ & $\mathrm{C}$ & $\mathrm{C}$ & $\mathrm{C}$ & $\mathrm{C}$ & $\mathrm{C}$ & \\
\hline 4 & 1018 & DIAMOND/PHOENIX & $\mathrm{B}^{+}$ & A & B & B & B & $\mathrm{B}^{+}$ & $\begin{array}{l}\text { road tube, loop sensor \& Piezo } \\
\text { inputs }\end{array}$ \\
\hline 5 & 1016 & DIAMOND/UNICORN & $\mathrm{B}^{+}$ & A & B & B & B & $\mathrm{B}^{+}$ & road tube \& loop sensor inputs \\
\hline 6 & 1026 & EIS RTMS & $\mathrm{C}$ & $\mathrm{C}$ & $\mathrm{C}$ & $\mathrm{B}$ & $\mathrm{D}$ & $\mathrm{D}$ & Side-fire radar-portable setup \\
\hline 7 & 1030 & $\begin{array}{l}\text { GOLDEN RIVER ARCHER } \\
\text { TUBE }\end{array}$ & C & $\mathrm{C}$ & B & $\mathrm{C}$ & $\mathrm{C}$ & $\mathrm{D}$ & \\
\hline 8 & 1030 & $\begin{array}{l}\text { GOLDEN RIVER } \\
\text { MARKSMAN } 3031\end{array}$ & B & A & B & A & B & B & \\
\hline 9 & & $\begin{array}{l}\text { INTERNATIONAL } \\
\text { TRAFFIC CO } \\
\end{array}$ & $\mathrm{C}$ & $\mathrm{C}$ & A & $\mathrm{C}$ & $\mathrm{C}$ & B & $\begin{array}{l}\text { software for processing data is not } \\
\text { good }\end{array}$ \\
\hline 10 & & $\begin{array}{l}\text { INTERNATIONAL } \\
\text { TRAFFIC CO/MINI TRS }\end{array}$ & C & $\mathrm{C}$ & B & A & $\mathrm{C}$ & B & \\
\hline 11 & & $\begin{array}{l}\text { INTERNATIONAL } \\
\text { TRFFIC CO/TRS }\end{array}$ & $\mathrm{D}$ & $\mathrm{D}$ & $\mathrm{D}$ & B & $\mathrm{C}$ & $\mathrm{C}$ & \\
\hline 12 & 1096 & JAMAR DB 100 & B & B & B & B & B & B & \\
\hline 13 & 1097 & $\begin{array}{l}\text { JAMAR DB } 400 \& \text { TDC- } \\
8\end{array}$ & B & A & B & B & A & A & \\
\hline 14 & 1097 & JAMAR DB-400 & A & A & A & & & & $\begin{array}{l}\text { have secondary buttons which } \\
\text { enables to track the movements of } \\
\text { trucks, buses, and pedestrians } \\
\text { separately }\end{array}$ \\
\hline 15 & 1097 & JAMAR IMC-IV & B & B & A & B & B & B & \\
\hline 16 & 1098 & JAMAR TDC-8 & $\mathrm{B}$ & A & A & B & B & A & \\
\hline 17 & 1098 & JAMAR TDC-8 & B & B & B & B & B & B & portable and easy to use \\
\hline
\end{tabular}




\begin{tabular}{|c|c|c|c|c|c|c|c|c|c|}
\hline \multicolumn{10}{|c|}{ Product Evaluation } \\
\hline ID & \begin{tabular}{|c|} 
Product \\
ID
\end{tabular} & Mode1 & $\begin{array}{c}\text { Overal1 } \\
\text { Grade }\end{array}$ & Accuracy & Reliability & Cost & $\begin{array}{c}\text { Training } \\
\text { Requirements }\end{array}$ & $\begin{array}{c}\text { Ease of } \\
\text { Installation/Maintenance } \\
\end{array}$ & 0ther Remarks \\
\hline 18 & 1098 & JAMAR TDC-8 & $\mathrm{A}$ & A & B & B & A & A & \\
\hline 19 & & NU-METRICs & B & A & B & B & B & B & \\
\hline 20 & & NU-METRICS & $\mathrm{C}$ & A & B & B & E & B & $\begin{array}{l}\text { need much work on validation after } \\
\text { installation }\end{array}$ \\
\hline 21 & 1056 & NU-METRICS $90 \mathrm{~A}$ & C & B & B & D & D & C & $\begin{array}{l}\text { difficult to interface with and not } \\
\text { being supported anymore }\end{array}$ \\
\hline 22 & 1057 & $\begin{array}{l}\text { NU-METRICS COUNT } \\
\text { CARD NC30X }\end{array}$ & B & A & $C-D$ & B & C & $\mathrm{B}-\mathrm{C}$ & $\begin{array}{l}\text { excellent technology; needs to be } \\
\text { more reliable }\end{array}$ \\
\hline 23 & 1056 & $\begin{array}{l}\text { NU-METRICS HI-STAR } \\
\text { NC-40 }\end{array}$ & $\mathrm{C}$ & A & $\mathrm{C}$ & D & $\mathrm{C}$ & $\mathrm{C}$ & high maintenance costs \\
\hline 24 & 1056 & $\begin{array}{l}\text { NU-METRICS HI-STAR } \\
\text { NC-90 }\end{array}$ & $\mathrm{C}$ & A & C & $\mathrm{D}$ & C & C & high maintenance costs \\
\hline 25 & 1056 & NU-METRICS/NC-97 & B & B & C & B & A & B & \\
\hline 26 & & PEEK 141 & $\mathrm{D}$ & $\mathrm{D}$ & $\mathrm{D}$ & $\mathrm{D}$ & $\mathrm{D}$ & $\mathrm{D}$ & \\
\hline 27 & & PEEK 241 & A & C & B & A & B & A & $\begin{array}{l}\text { tubes vandalized or removed during } \\
\text { counts; caught in sweepers }\end{array}$ \\
\hline 28 & & PEEK 241 & B & B & B & C & B & B & \\
\hline 29 & & PEEK 241 EZ & C & C & C & C & B & B & \\
\hline 30 & 1070 & PEEK ADR 1000 & B & A & C & C & B & C & \\
\hline 31 & 1070 & PEEK ADR 1000 & A & B & A & B & B & B & \\
\hline 32 & 1070 & PEEK ADR 1000 & A & A & B & B & C & B & \\
\hline 33 & 1070 & PEEK ADR 1000 & B & B & B & B & B & B & \\
\hline 34 & 1070 & PEEK ADR 1000 & $\mathrm{~A}$ & A & A & $\mathrm{B}$ & B & B & \\
\hline 35 & 1070 & $\begin{array}{l}\text { PEEK ADR } 1000 \& \\
2000 \text { SERIES }\end{array}$ & A & A & A & A & $C-D$ & A & $\begin{array}{l}\text { good technical support; software is } \\
\text { complex }\end{array}$ \\
\hline 36 & 1069 & PEEK ADR 2000 & B & A & $\mathrm{C}$ & C & $\mathrm{C}$ & C & \\
\hline
\end{tabular}




\section{Product Evaluation}

\begin{tabular}{|c|c|c|c|c|c|c|c|c|c|}
\hline ID & $\begin{array}{c}\text { Product } \\
\text { ID }\end{array}$ & Model & $\begin{array}{c}\text { Overal1 } \\
\text { Grade }\end{array}$ & Accuracy & Reliability & Cost & $\begin{array}{c}\text { Training } \\
\text { Requirements }\end{array}$ & $\begin{array}{c}\text { Ease of } \\
\text { Installation/Maintenance }\end{array}$ & 0ther Remarks \\
\hline 37 & & PEEK TRAFFICOMP III & $\mathrm{C}$ & $\mathrm{C}$ & B & $\mathrm{B}$ & B & $\mathrm{C}$ & \\
\hline 38 & & PEEK TRAFFICOMP III & B & B & $\mathrm{D}$ & $\mathrm{C}$ & $\mathrm{C}$ & B & \\
\hline 39 & & $\begin{array}{l}\text { PEEK TRAFICOMP } \\
\text { III } / 241\end{array}$ & B & B & B & B & B & $\mathrm{C}$ & \\
\hline 40 & 1089 & TIMEMARK DELTA 3 & $\mathrm{C}$ & $\mathrm{C}$ & $\mathrm{C}$ & $\mathrm{D}$ & $\mathrm{D}$ & $\mathrm{C}$ & \\
\hline 41 & 1089 & $\begin{array}{l}\text { TIMEMARK DELTA AND } \\
\text { LAMDA }\end{array}$ & A & A & A & A & A & A & battery charge is not convenient \\
\hline 42 & 1089 & TIMEMARK DELTA I & A & A & B & A & A & $\mathrm{B}-\mathrm{C}$ & \\
\hline 43 & 1089 & TIMEMARK DELTA III & A & B & B & & C & B & \\
\hline 44 & 1089 & TIMEMARK DELTA III & B & A & B & B & A & A & \\
\hline 45 & 1090 & $\begin{array}{l}\text { TIMEMARK GAMMA } \\
\text { COUNTER }\end{array}$ & A & B & B & B & C & A & \\
\hline
\end{tabular}


Appendix E: User Manual for the Databases in Microsoft Access 


\section{Basic Concepts of Microsoft Access}

Microsoft Access is a relational database management system. Relational databases are those where the data is held in a number of cross-referenced files in order to reduce duplication. This makes it easier to find, analyze, maintain and protect the data, and bridge the relationships between related databases.

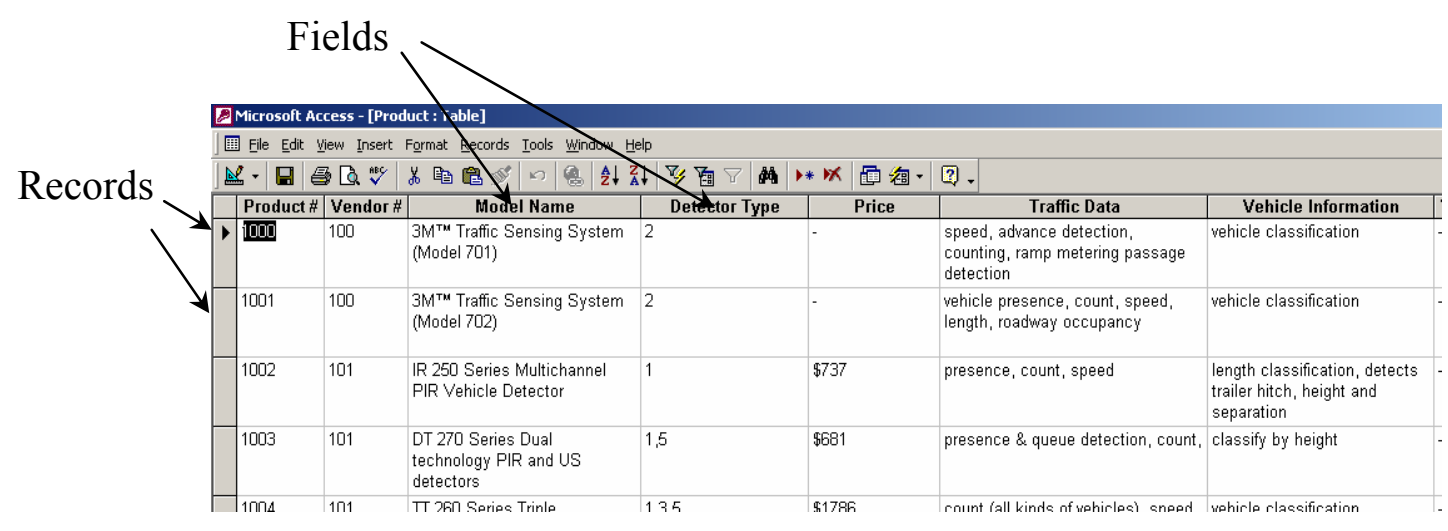

Figure E-1 Example of Access Datasheet

In Access, a collection of data about an individual item is called "record". Data is stored in the form of files. Each file may contain one or more relational databases, which are represented by tables. The view of table is called a "datasheet". Datasheet is the mechanism by which Access commonly stores and shows data. A datasheet typically composes of a set of related records that have some common attributes, or "fields", which is a single item of data common to all records. Each record has some particular values for all the entries of its fields. "Primary keys" is one or more fields that uniquely identify each record in the table. Figure E-1 shows an example of a table (database) within which each row represents a record and each column represents a field within the record.

In order to manipulate, process, and represent the data, a tool called "form" is used. Form can be utilized to create database, and input, edit or view information in the 
database record by record. After the construction of the database, information can be obtained according to particular criteria or usage. This procedure is called "query". A "report" can be built to produce the information in the specified format. Report also provides group information or certain results such as totals and average.

\section{General Instructions}

To start Microsoft Access, locate the Microsoft Access icon from the Windows Start menu, and then click the Access icon. The initial screen will be displayed. The Access window follows the standard layout for all Microsoft Windows applications. A Title Bar is displayed at the top of the window with a Control Menu box to the left and Minimize, Restore and Close buttons to the right. Underneath is the Menu bar and below that is the Tool Bar (Figure E-2). The Microsoft Access toolbar contains buttons that provide shortcuts for commands found in the menu bar.

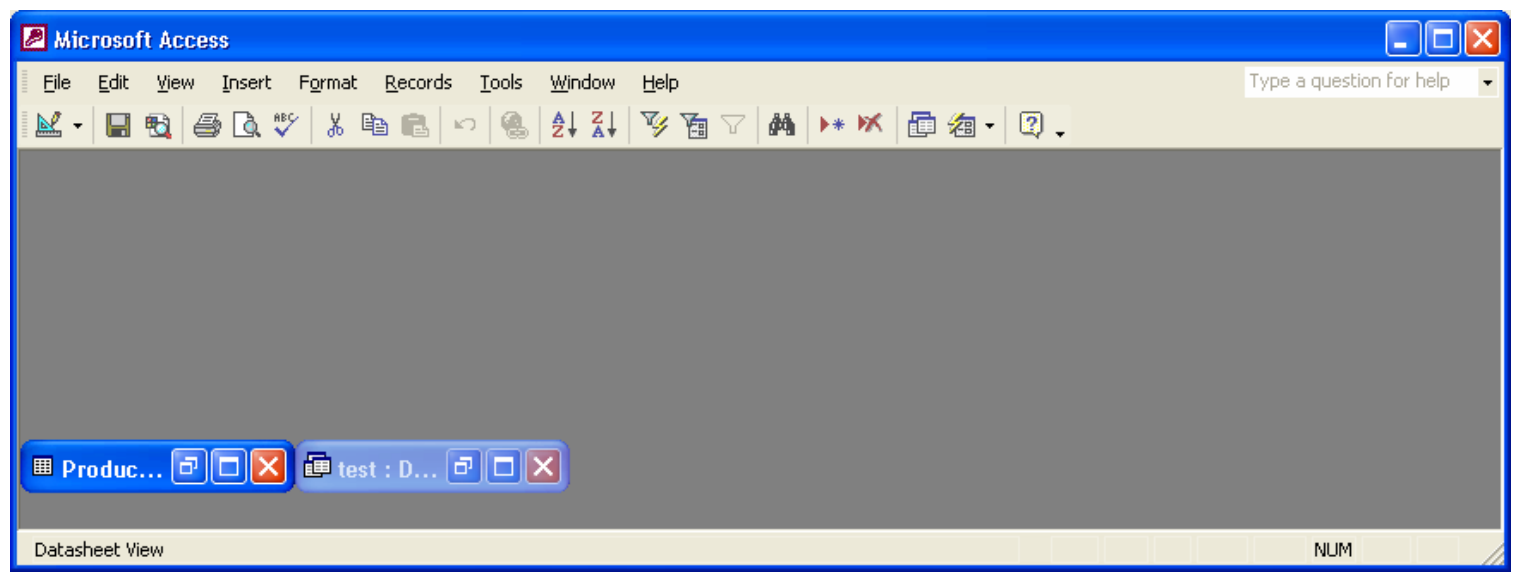

Figure E-2 Access Application Window

Following common Windows application procedures, an existing file can be opened or a new file can be created after Microsoft Access is started. For example, a data 
file called "main.mdb" stored under the "Database" directory on CD-R (D: Drive) can be opened from the path "D: $\mid$ Database $\backslash$ main.mdb".

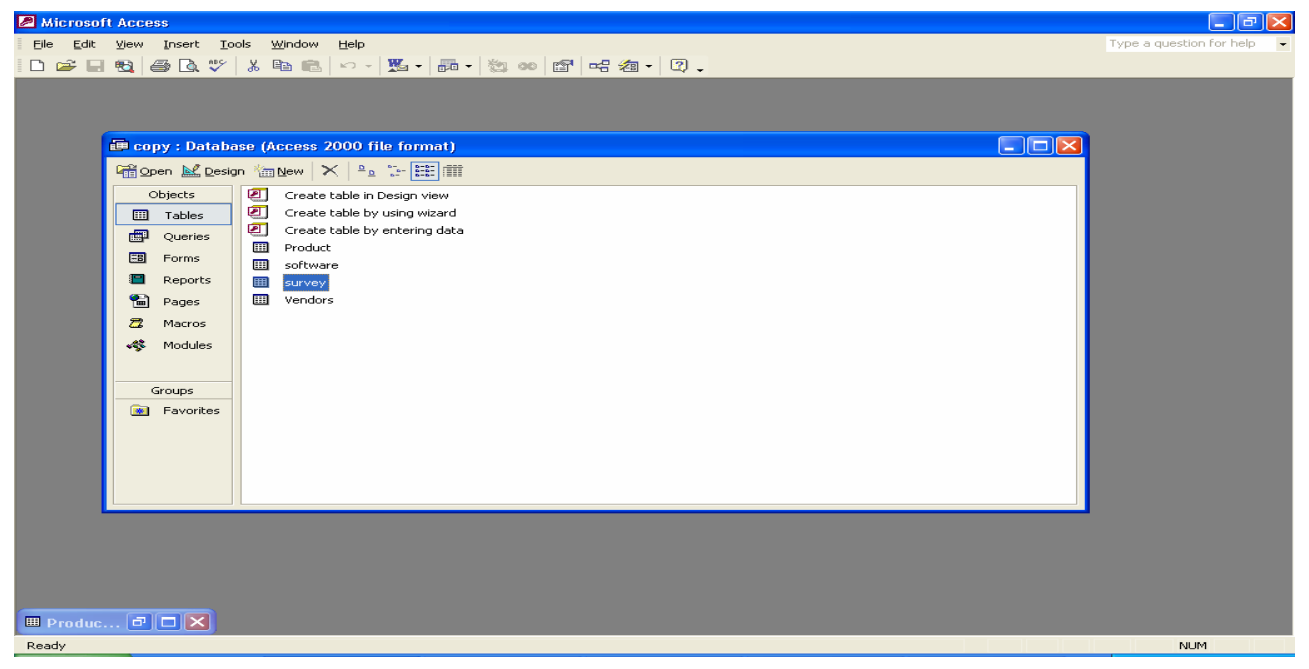

Figure E-3 Access Database Window

After opening a file, the Database Window appears within the Access application window (Figure E-3). Icons on the left hand side provide access to tables, queries, forms, reports, macros and modules. To open a table, click a table icon in the database window (Figure E-4).

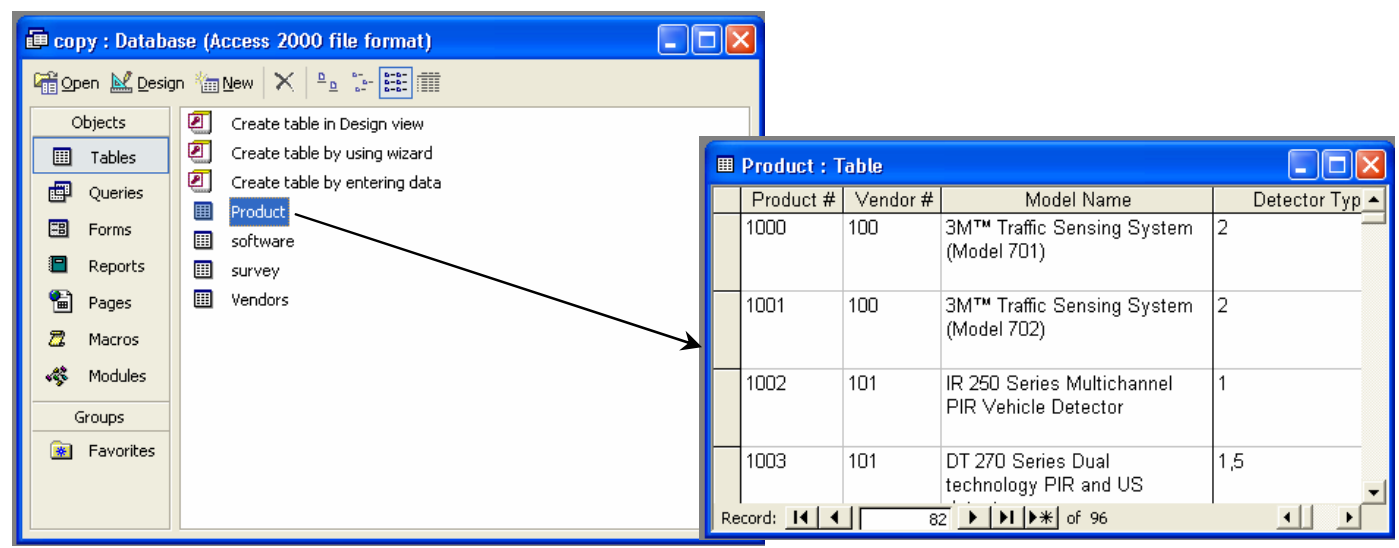

Figure E-4 Opening Data Table

A table opened from the database window appears as a datasheet. Column headings immediately beneath the title bar denote field names. Each row contains a 
separate record. The table might have more columns than can be displayed in the window, in which case only the leftmost ones are visible. The shaded boxes to the left of the records are known as record selectors. An arrow symbol in the selector indicates the record currently selected. At the bottom of the window, immediately above the status line, a scroll bar provides navigation buttons and boxes showing the number of the current record and the total number of records in the table.

There are several ways to view or manipulate data. One of the most common ways is query, which provides a way to gather selected information from the database with respects to the values of some fields. Data can be selected from tables and can be combined together. One can specify criteria to limit the number of records and perform calculations to produce information not directly held in the underlying tables. A parameter query asks for criteria to be inserted by the user interactively. When the user runs the query, it displays a dialog box or boxes requesting the criteria. Another method to show information is form. Forms present the user with a friendlier view of the database. Forms can be used in a variety of ways including adding, deleting and modifying data; displaying data; controlling the way and order in which users access the database; and printing of information. All forms are based on one or more underlying tables whose structure is unaffected by the form design. A third way of showing data is through reports. Reports are the traditional form of output. Although they can be previewed on the screen, report is generally more useful for printing hard copy. It provides a convenient way to group, sort, and summarize huge amounts of information and present it in a readable format. 


\section{LIST OF REFERENCES}




\section{LIST OF REFERENCES}

Bahler, S. J., J. M. Kranig, and J. M. Minge, "Field Test of Non-intrusive Traffic Detection Technologies". Transportation Research Record No. 1643, Transportation Research Board, Washington D.C., 1998. pp. 161-170.

Faghri, A., M. Glaubitz, and J. Parameswaran, "Development of an Integrated Traffic Monitoring System for the State of Delaware", Transportation Research Record No. 1536, Transportation Research Board, Washington D.C., 1998, pp. 40-44.

Federal Highway Administration (FHWA), “Traffic Monitoring Guide, Third Edition", Publication Number FHWA-PL-95-031, FHWA, Washington, D.C., February 1995.

Federal Highway Administration (FHWA), Minnesota Department of Transportation, Minnesota Guidestar Program, and SRF Consulting Group, Inc., "Field Test of Monitoring of Urban Vehicle Operations Using Non-intrusive Technologies”, Final Report, Publication Number FHWA-PL-97-018, FHWA, Washington, D.C., May 1997.

Grenard, J., A. Tarko and D. Bullock, "Evaluation of Selected Video Detection Systems at Signalized Intersections", Research Project FHWA/IN/JTRP-2001/22, File Number 8-4-52, Draft Final Report, Joint Transportation Report, Purdue University, West Lafayette, November 2001.

Hallenback, M. E., "Development of an Integrated Statewide Traffic Monitoring System”, Transportation Research Record No. 1050, Transportation Research Board, Washington D.C., 1995. pp. 5-12.

Hughes Aircraft Corporation, "Select and Obtain Vehicle Detectors", Final Report, Hughes Aircraft Corporation and FHWA, Fullerton, California, 1993.

Klein, L.A., Vehicle Detector Technologies for Traffic Management Applications, ITS online, http://www.itsonline.com/detect_pt1.html, visited on January 8, 2002.

Krogmeier, J.V., K.C. Sinha, M. P. Fitz, S. Peeta, and S. Y. Nof, “Borman Expressway ATMS Equipment Evaluation", Research Project FHWA/IN/JHRP-96/15, Final Report, Joint Transportation Research Project, Purdue University, West Lafayette, IN, August 1996. 
Mimbela, L.E. and Klein, L.A., "Summary of Vehicle Detection and Surveillance Technologies used in Intelligent Transportation Systems", The Vehicle Detector Clearing House Project, FHWA, New Mexico State University, Las Cruces, New Mexico, November 2000. http://www.nmsu.edu/ traffic/, visited on 2/5/2002. 